\title{
KONCEPT STVARNE NADLEŽNOSTI SUDOVA U PLOVIDBENIM SPOROVIMA (ANALIZA DE LEGE LATA)
}

\author{
Dr. sc. Vesna Skorupan Wolff*
}

\author{
UDK 347.79 \\ https://doi.org/10.30925/zpfsr.39.2.9 \\ Ur.: 16. ožujka 2018. \\ Pr.: 7. lipnja 2018. \\ Prethodno priopćenje
}

\section{Sažetak}

Cilj je rada pružiti jezično i teleološko tumačenje odredbe članka 34.b stavka 1. t. 6. Zakona o parničnom postupku, koja propisuje da su za postupanje u plovidbenim sporovima stvarno nadležni trgovački sudovi, a primjenom kauzalnoga kriterija određuje koji se sporovi smatraju plovidbenim sporovima. Precizne smjernice (teorijske i praktične) o točnoj primjeni ove odredbe nisu dane u domaćoj literaturi. To je vjerojatno jedan od uzroka čestih sukoba stvarne nadležnosti između općinskih i trgovačkih sudova nastalih u njezinoj primjeni. Osim što je rad usmjeren na obrazloženje koncepta stvarne nadležnosti prema navedenoj odredbi, njegova je zadaća prikaz i komentar relevantne sudske prakse u pomorskim sporovima u kojima se kao sporno pojavilo pitanje koji je sud stvarno nadležan. Nastoje se dati smjernice za točnu interpretaciju sadržaja i domašaja pojedinih komponenti kauzalnoga kriterija: a) sporovi koji se odnose na brodove, b) sporovi koji se odnose na plovidbu morem i c) sporovi na koje se primjenjuje plovidbeno pravo (plovidbeni sporovi), a na temelju toga precizno odrediti za koje su sporove prema članku 34.b stavku 1. t. 6. ZPP-a nadležni trgovački sudovi. ${ }^{1}$

* Dr. sc. Vesna Skorupan Wolff, znanstvena savjetnica Jadranskog zavoda Hrvatske akademije znanosti i umjetnosti; vesnas@hazu.hr.

Rad je rezultat istraživanja u okviru znanstvenoistraživačkog projekta Jadranskog zavoda Hrvatske akademije znanosti i umjetnosti pod nazivom Razvoj suvremenog pravnog $i$ osigurateljnog režima za hrvatske marine unapređenje konkurentnosti, sigurnosti, sigurnosne zaštite i zaštite morskog okoliša (DELICROMAR), financiranog od Hrvatske zaklade za znanost, www.delicromar.hazu.hr.

1 Ovaj rad predstavlja prvi dio cjelovitog istraživanja koncepta stvarne nadležnosti sudova u plovidbenim sporovima i odnosi se na analizu na razini de lege lata. Drugi dio istraživanja odnosi na analizu koncepta stvarne nadležnosti sudova u plovidbenim sporovima de lege ferenda i bit će prezentiran u posebnom radu. U tome radu razmatrat će se razlozi zbog kojih su potrebne izmjene i dopune postojećeg koncepta stvarne nadležnosti za pomorske sporove. Iznijet će se prijedlozi de lege ferenda koji se odnose na izmjene i dopune Pomorskog zakonika, a koji će izravno utjecati na opseg i doseg primjene čl. 34.b st. 1. t. 6. ZPP-a te cjelokupan koncept stvarne nadležnosti sudova u pomorskim sporovima. Osim elaboriranja i tumačenja razloga zbog kojih svi sporovi koji imaju pomorskopravni karakter trebaju biti u nadležnosti trgovačkih sudova i svih reperkusija koje će na stvarnu nadležnosti sudova imati noveliranje 


\section{Ključne riječi: plovidbeni sporovi, stvarna nadležnost, sukob stvarne nadležnosti, plovidbeno pravo.}

\section{UVOD}

U domaćoj poslovnoj praksi sudovi su najčešće korištena tijela (medij) za rješavanje pomorskih sporova. Stoga je pitanje koji je sud stvarno nadležan iznimno važno i pojavljuje se istodobno s donošenjem odluke hoće li stranka (tužitelj) voditi spor pred sudom.

Odredbe o stvarnoj nadležnost suda sadržane su u Pomorskom zakoniku ${ }^{2}$ i Zakonu o parničnom postupku, ${ }^{3}$ pa oni služe kao pravni izvori kojima se određuje stvarna nadležnost suda u konkretnom sporu iz ove materije. ${ }^{4}$

Premda sudske odluke koje se bave pomorskim sporovima nisu brojne u domaćoj judikaturi, interesantno je da je priličan broj onih u kojima su sudovi raspravljali o stvarnoj nadležnosti u pomorskim sporovima. Riječ je o slučajevima sukoba stvarne nadležnosti kada se prvostupanjski sud pred kojim je pokrenut postupak (općinski sud ili trgovački sud), oglasio stvarno nenadležnim, a sud kojem je predmet ustupljen na postupanje i odlučivanje nije prihvatio nadležnost, pa je nastao sukob nadležnosti između sudova različite vrste. Vrhovni sud Republike Hrvatske u parničnom postupku rješava sukob nadležnosti između općinskih i trgovačkih sudova kao sud koji im je zajednički neposredno viši sud. ${ }^{5}$

Česti slučajevi sukoba stvarne nadležnosti u pomorskim sporovima stvaraju niz negativnih posljedica za stranke involvirane u sporove, ali i za same sudove. Dovodi se u pitanje efikasnost i ekonomičnost sudskog postupka, dolazi do njegove značajne prolongacije, ${ }^{6}$ stvaraju se dodatni troškovi, opterećuje se više različitih sudova (općinski, trgovački te Vrhovni sud Republike Hrvatske koji odlučuje o sukobu nadležnosti). Nadalje, ono što je najvažnije, nejedinstvena sudska praksa stvara pravnu nesigurnost za stranke pri izboru stvarno nadležnog suda, a sve zajedno može negativno utjecati i na poslovnu praksu. Znači, kratko rečeno posljedice su znatne i

Pomorskog zakonika koje je u tijeku, ispitat će se i učinci koji će se postići inkluzijom sporova koji se odnose na brodice u stvarnu nadležnost trgovačkih sudova.

2 Pomorski zakonik, Narodne novine, br. 181/2004, 43/2006, 76/2007, 146/2008, 61/2011, 56/2013, 26/2015 (u nastavku PZ).

3 Zakon o parničnom postupku Narodne novine br. 53/1991, 91/1992, 112/1999, 88/2001, 117/2003, 88/2005, 2/2007, 84/2008, 96/2008, 123/2008, 57/2011, 148/2011 - pročišćeni tekst, 25/2013 (u nastavku ZPP).

4 PZ kao poseban propis pravni je izvor koji propisuje stvarnu nadležnost trgovačkog suda za: a) sve sporove između članova posade i brodara (čl. 164. PZ-a) te b) ovršne predmete koji se odnose na ovrhu i osiguranje na brodu i teretu. ZPP uređuje opseg stvarne nadležnosti sudova u parničnom postupku i to općinskih sudova (čl. 34. ZPP), trgovačkih sudova (čl. 34.b ZPP), Visokog trgovačkog suda Republike Hrvatske (čl. 34.c ZPP-a) te Vrhovnog suda Republike Hrvatske (čl. 34.d ZPP-a).

5 Čl. 34.d st. 1. toč. 3. ZPP-a.

6 Predmet putuje s jednog suda na drugi, konkretno sa suda koji smatra da nije nadležan na sud koji ne prihvaća nadležnost i izaziva sukob stvarne nadležnosti te na kraju dolazi na Vrhovni sud Republike Hrvatske koji nakon svoje odluke vraća spis stvarno nadležnom sudu. 
dalekosežne.

Odredba članka 34.b stavka 1. t. 6. ZPP-a u praksi je najčešće primjenjivani izvor pri određivanju stvarne nadležnosti sudova u pomorskim sporovima, pa je njoj posvećena iscrpna analiza u ovom radu. Stvarna nadležnost trgovačkog suda prema ovoj odredbi definirana je primjenom kauzalnog kriterija. Propisano je da trgovački sudovi u parničnom postupku u prvom stupnju sude u plovidbenim sporovima. Prema definiciji zakonodavca plovidbeni sporovi su sporovi koji se odnose na: a) brodove i b) plovidbu na moru i unutrašnjim vodama te c) sporovi na koje se primjenjuje plovidbeno pravo.

U određivanju polja primjene članka 34.b stavka 1. t. 6. ZPP-a zakonodavac je taksativno, a ne egzemplikativno, utvrdio opseg karakteristika, točnije naveo kategorije sporova na koje se članak primjenjuje. One predstavljaju objektivne komponente kauzalnoga kriterija za određivanje stvarne nadležnosti. Navedene tri komponente kauzalnoga kriterija definiraju posebne skupine sporova na koje se članak 34.b stavak 1. t. 6. ZPP-a primjenjuje, a krug komponenti kauzalnoga kriterija ne može se ni proširiti ni suziti.

Precizne smjernice (teorijske i praktične) o točnoj primjeni ove odredbe nisu dane u domaćoj literaturi. Naime, osim dvaju radova autorica Skorupan Wolff i Padovan $^{7}$ i Padovan i Skorupan Wolff ${ }^{8}$ koji obrađuje pitanja stvarne nadležnosti za sporove iz ugovora o vezu, suvremene literature o ovoj temi nema. U starijoj domaćoj pravnoj književnosti nekoliko pisaca na znanstvenoj razini proučavalo je nadležnost u pomorskim sporovima i općenito nadležnost domaćih trgovačkih sudova: Pallua i Jakaša; ${ }^{9}$ Pallua; ${ }^{10}$ Šuc; ${ }^{11}$ Stanković; ${ }^{12}$ Radionov ${ }^{13}$; Zuglia i Triva; ${ }^{14}$ Dika; $;{ }^{15}$ Brežanski; ${ }^{16}$

7 Skorupan Wolff, V., Padovan, A. V., Smjernice za pravilan odabir stvarno nadležnog suda u sporovima iz ugovora o vezu u marini te zakonski prijedlozi de lege ferenda, Proceedings Book 1st International Scientific Conference of Maritime Law „Modern Challenges of Marine Navigation”, Split, Croatia, 29-30 September 2016 (ISCML, Split, 2016.), str. 379-420.

8 Padovan, A. V., Skorupan Wolff, V., The Repercussions of the Legal Definitions of Ship, Yacht and Boat in The Croatian Maritime Code on the Court Competence Ratione Materiae in Disputes Arising from Berthing Contracts, The Ship: an Example of Legal Pluri-Qualification, Il Diritto Marittimo - Quaderni, 3, Editor Massimiliano Musi, ASLA, BONOMO EDITORE, 2016., p. 249-277.

9 Pallua, E., Jakaša, B., Pomorski sporovi u jugoslavenskom pravu, Zbornik Pravnog fakulteta u Zagrebu, god. X (1960), br. 3-4, str. 258.-268.

10 Pallua, E., Nekoliko napomena o odredbama Zakona o parničnom postupku u pomorskim sporovima, Naša zakonitost, (1958) br. 4., str. 135-142.

$11 \breve{S u c}$, A., Neka pitanja u vezi stvarne nadležnosti u pomorskim sporovima, Naša zakonitost, god. IX (1955), br. 6-7, str. 261-266.

12 Stanković, G., Neka pitanja stvarne nadležnosti sudova u pomorskim stvarima, Pomorski zbornik 34 (1996), br. 1., str. 213-229.

13 Radionov, N., Nadležnost suda u sporu za naknadu štete zbog tjelesne povrede putnika nastale uslijed sudara brodova, Hrvatska pravna revija, god. 2 (2002), br. 7, str.129-132.

14 Zuglia, S., Triva, S., Komentar Zakona o parničnom postupku, vol. II, Narodne novine, Zagreb, 1957.

15 Dika, M., Stvarna nadležnost trgovačkih sudova u parničnom i izvršnom postupku, Pravo u gospodarstvu, 33 (1994), br. 7-8, str. 542-553.

16 Brežanski, J., Rješavanje sukoba nadležnosti u praksi Vrhovnog suda Hrvatske, Naša zakonitost, 
Eraković. ${ }^{17}$ To je vjerojatno jedan od uzroka čestih sukoba stvarne nadležnosti između općinskih i trgovačkih sudova nastalih u primjeni ove odredbe te posljedično tomu pravne nesigurnosti za stranke u postupku u pogledu izbora stvarno nadležnog suda.

Niti sama odredba članka 34.b stavka 1. t. 6. ZPP-a ne pojašnjava odnose između vlastitih pravila i dijelova odredbe, točnije pojedinih komponenti kauzalnoga kriterija: a) spor koji se odnosi na brod, b) spor koji se odnosi na plovidbu morem i c) spor na koji se primjenjuje plovidbeno pravo. Na tom tragu, s obzirom na to da nedostaje jasan kriterij za vrednovanje pojedinih komponenti kauzalnog kriterija, cilj je detaljno propitati, raspraviti i ocijeniti kakva je faktična uloga u praksi pojedine od navedene tri komponente. Naime, pođe li se od toga da zakon «ravnopravno» nabraja tri navedene komponente, treba odgovoriti ima li u praksi isti učinak (efekt) prisutnost pojedine od te tri komponente. Tumačenje članka 34.b stavka 1. t. 6. ZPP-a je očito složeno i slojevito, a brojni sukobi nadležnosti u praksi to pokazuju, pa je potrebno izraditi sustavan i detaljan prikaz legislativnog i teorijskog okvira za njegovo tumačenje.

Prikazat će se relevantna sudska praksa u kojoj je došlo do sukoba nadležnosti između prvostupanjskih sudova općinskog i trgovačkog, a u kojoj je Vrhovni sud Republike Hrvatske odlučivao o sukobu nadležnosti i odredio koji je sud stvarno nadležan. ${ }^{18}$ Analiza i komentar judikature koja se odnosi na rješavanje sukoba nadležnosti kao i one u kojoj se kao sporno pojavilo pitanje koji je sud stvarno nadležan u konkretnom sporu, uz spomenutu analizu legislativnog okvira omogućit će da se utvrde poteškoće u praksi u tumačenju propisa i odgovori zašto dolazi do čestih sukoba nadležnosti.

Uzimajući u obzir sva otvorena pitanja, ciljevi ovog rada su analizirati uvjete prema kojima se za određeni spor smatra da ulazi u okvir članka 34.b stavka 1. t. 6. ZPP-a te detaljno analizirati značenje, sadržaj i domašaj sve tri komponente kauzalnoga kriterija koje predviđa članak 34.b stavak 1. t. 6. ZPP-a. Nastoje se pružiti smjernice za pravilno tumačenje članka 34.b stavka 1. t. 6. ZPP-a, a time i pravilan izbor stvarno nadležnog suda u konkretnom sporu. Teorijske smjernice, ali i interpretativno rješenje koje omogućuje, s razumnom razinom sigurnosti pravilan odabir stvarno nadležnog suda u konkretnom sporu, trebali bi poslužiti onima koji se u praksi susreću s problemom izbora stvarno nadležnog suda u pomorskim sporovima.

\section{OPĆE NAPOMENE O STVARNOJ NADLEŽNOSTI SUDOVAU POMORSKIM SPOROVIMA}

Zakonodavac propisivanjem stvarne nadležnosti, kategorizira sudove i građanske/trgovačke predmete na taj način da, in abstracto, utvrđuje koja će vrsta sudova rješavati određene vrste građanskih odnosno trgovačkih predmeta u prvom

god. 43 (1989), br. 9-10, str. 1219-1226.

17 Eraković, A., Stvarna nadležnost trgovačkih sudova, Pravo i porezi, vol. 6 (1997) br. 6. str. 2733.

18 U ovom će se radu za označavanje judikata i njihovih izvora upotrebljavati kratice. Rabe se sljedeće kratice: Vrhovni sud Republike Hrvatske - VSRH, Vrhovni sud Hrvatske - VSH, Visoki trgovački sud Republike Hrvatske - VTS, Trgovački sud - TS, Okružni privredni sud OPS, Županijski sud - ŽS, Općinski sud - OS. 
stupnju, a ne određuje, in concreto, koji će sud na teritoriju Republike Hrvatske raspravljati o konkretnom sporu i rješavati ga. U teoriji postoji nekoliko kriterija za razgraničenje stvarne nadležnosti: kriteriji s obzirom na predmet spora, tzv. kauzalni kriterij (competentia ratione causa); mješoviti kauzalno personalni kriterij; kriteriji s obzirom na procesne subjekte, tj. kriterij svojstva stranaka u postupku, tzv. personalni ili osobni kriterij (competentia ratione personae); kriterij vrijednosti predmeta spora (competentia ratione valoris) te atrakcijski kriterij. ${ }^{19}$

Kauzalni kriterij primjenjuje upravo odredba čl. 34. b st. 1. t. 6. ZPP-a čije je tumačenje predmet ovog rada. Kauzalni kriterij za određivanje stvarne nadležnosti zasniva se s jedne strane na isticanju predmeta spora, odnosno spominjanju građe zastupljene u tim sporovima (brodovi i plovidba na moru) te, s druge strane na isticanju vrste spora, odnosno prava koje se na te sporove primjenjuje, pa se govori o sporovima na koje se primjenjuje plovidbeno pravo. Mješoviti kauzalno personalni kriterij mjerodavan je za određivanje stvarne nadležnosti trgovačkih sudova u sporovima koji proizlaze iz trgovačkih ugovora (čl. 34. b st. 1. t. 1. ZPP-a). Uzima se u obzir ne samo vrsta spora (kauzalna komponenta), već i personalna komponenta, znači, osobe između kojih je došlo do spora. Personalni kriterij za određivanje stvarne nadležnosti primjenjuje članak 164. PZ-a. Propisano je da su za suđenje u svim sporovima između člana posade broda i brodara, ili poslovođe, ili kompanije, te zapovjednika i brodara, ili poslovođe ili kompanije nadležni trgovački sudovi nadležni za pomorske sporove. ${ }^{20}$ Odredba članka 34.b stavka 1. t. 5. ZPP-a, primjenom atrakcijskoga kriterija, ${ }^{21}$ uspostavlja nadležnost trgovačkih sudova u svim sporovima u kojima je stranka osoba nad kojom je otvoren stečajni postupak bez obzira na svojstvo druge stranke te sve sporove u povodu stečaja, osim ako nije riječ o sporovima u kojima prema ZPP-u uvijek sudi općinski sud (čl. 34. st. 1.), odnosno ako nije riječ o sporovima za koje je zakonom utvrđena nadležnost nekog drugog suda. Sporovi koji su pokrenuti prije nastupanja pravnih posljedica otvaranja stečaja, dovršit će se pred sudovima pred kojima su pokrenuti.

Postojeći koncept stvarne nadležnosti sudova u pomorskim sporovima (uz

19 Opširnije SKORUPAN WOLFF i PADOVAN, op. cit., bilješka 7., str. 384.

20 Odredba čl. 161. st. 4. PZ-a iz 1994. (Narodne novine, br. 17/94, 74/94, 43/96) koja je govorila o stvarnoj nadležnosti sudova za sporove između članova posade i brodara bila je predmet sudskog tumačenje $u$ pogledu pitanja primjenjuje li se ova odredba samo na sporove u vezi s naknadom štete ili na sve međusobne sporove između navedenih osoba. VSRH je u odluci Gr1962/02-2 od 18. prosinca 2002 iznio jasno stajalište o njezinoj primjeni. Istaknuo je da odredbu čl. 161. st. 4. PZ-a iz 1994. treba tumačiti ekstenzivno. Tom odredbom stvarna nadležnost trgovačkih sudova propisana je za sve međusobne sporove između članova posade broda i brodara, kao i za sve međusobne sporove između zapovjednika broda i brodara, a ne samo za sporove između ovih osoba radi naknade štete. Dakle, citiranom odredbom stvarna nadležnost trgovačkog suda određena je s obzirom na svojstvo subjekata, a ne vrstu spora. Okolnost što je ona u nomotehničkom smislu sastavni dio čl. 161. PZ-a ne daje osnovu za restriktivno tumačenje da se ona odnosi samo na sporove između navedenih osoba radi naknade štete zbog tjelesne ozljede i smrti člana posade broda.

21 Atrakcijski kriterij jest takav kriterij kod kojega se izbor stvarno nadležnog suda temelji na okolnosti da se već vodi ili da se može voditi određeni spor. 
izmjene u pogledu sporova koji se odnose na prijevoz putnika ${ }^{22}$ ) postoji od 1954 . godine, kada je u nas uspostavljeno trgovačko sudovanje. Potreba za specijaliziranim trgovačkim sudovima javila se odmah nakon donošenja Hrvatskog trgovačkog zakona 1875. godine, uz isticanje da su nakon njegovog donošenja potrebna posebna znanja onih koji rješavaju trgovačke i mjenične sporove, jer ih nalažu posebnosti trgovačkih poslova, koji su mnogo složeniji i u pravilu veće vrijednosti od onih u građanskopravnim odnosima. Odlučeno je da se ovlaste samo neki sudovi za suđenje u trgovačkim sporovima, pritom nije bila sporna potreba za specijalizacijom, ali su odlučni bili financijski razlozi, tj. nedostatak sredstava, okolnost da trgovački pravni promet nije bio toliko jak. Za suđenje u trgovačkim i mjeničnim stvarima bili su u prvom stupnju nadležni kraljevski sudbeni stolovi koje s obzirom na potrebe prometa naredbom odredi ban. Trgovačko sudstvo, iako ne pod tim nazivom prvi puta se predviđalo u Osnovnom zakonu o državnim privrednim poduzećima iz 1946. godine, kada je bio donesen i Zakon o rješavanju imovinskih sporova državnom arbitražom. $\mathrm{Na}$ temelju tog zakona sve imovinske sporove između tadašnjih poduzeća rješavala je Državna arbitraža. Iako nije bilo riječ o sudovima, državne arbitraže obavljale su funkciju sudovanja u gospodarstvu, koje je time bilo izuzeto iz djelokruga redovitih sudova. O pravom trgovačkom sudstvu može biti riječ tek otkad je 1954. godine bio donesen Zakon o privrednim sudovima, kojim je bilo ustrojeno trgovačko sudstvo $\mathrm{u}$ okružnim privrednim sudovima, Visokom privrednom sudu i Vrhovnom privrednom sudu. Na tome se i danas temelji ustroj trgovačkog sudstva u Republici Hrvatskoj (trgovački sudovi, Visoki trgovački sud, Vrhovni sud Republike Hrvatske). ${ }^{23}$

Većina pomorskih sporova ulazi u djelokrug trgovačkih sudova, a u prilog takve podjele stvarne nadležnosti ističe se više razloga. Postupanje i odlučivanje u pomorskim sporovima povjerava se trgovačkim sudovima zbog društvenog značaja pomorskih sporova, nerijetko je riječ o sporovima velikih vrijednosti, stranke u postupku su $\mathrm{u}$ pravilu pravne osobe, profesionalci koji u pravnom prometu trebaju postupati s povećanom pažnjom, riječ je o sporovima u vezi s njihovom djelatnošću, nadalje, pomorsko pravo u velikom broju instituta odstupa od klasičnih načela građanskog i trgovačkog prava, a unifikacija je na međunarodnoj razini postignuta donošenjem brojnih međunarodnih konvencija pomorskog prava od kojih velik broj međunarodnih konvencija počiva na općim načelima i pojedinačnim rješenjima angloameričkoga pravnog sustava. Stoga je poželjno da sudovi nadležni za odlučivanje u pomorskim sporovima imaju određenu razinu specijaliziranog poznavanja pomorskog prava te poslovne prakse i sudske prakse u ovoj vrsti sporova. ${ }^{24}$

Prema aktualnoj legislativi koju čine ZPP kao kompetencijski zakon te PZ kao lex

22 Izmjenama i dopunama čl. 34.b st. 1. t. 6. ZPP-a (Narodne novine, br. 25/2013, stupio na snagu 1. travnja 2013.) izvršena je inkluzija sporova o prijevozu putnika u nadležnost trgovačkih sudova.

23 Barbić, J., Trgovačko sudstvo u Hrvatskoj, 50th Anniversary of the Commercial Court sin the Republic of Croatia 1954-2004, Visoki trgovački sud Republike Hrvatske, Zagreb, 2004., str. 16.-21.

24 Takvo shvaćanje podupiru: STANKOVIĆ, op. cit., bilješka 12., str. 227; PALLUA i JAKAŠA, op. cit., bilješka 9., str. 258; SKORUPAN WOLFF I PADOVAN, op. cit., bilješka 7., str. 385; PADOVAN i SKORUPAN WOLFF, op. cit., bilješka 8., str. 258-261. 
specialis za uređenje pomorsko pravne materije, sporovi koji imaju pomorskopravni karakter ulaze u više jurisdikcija. Znači, svi sporovi koji imaju pomorskopravni karakter nisu sporovi za koje su nadležni trgovačkih sudovi, nerijetko dolazi u obzir i stvarna nadležnost općinskih sudova i to u onim sporovima koji se odnose na brodice. U nastavku ovoga rada kritički se raspravlja o primjeni članka 34.b stavka 1. t. 6. ZPP-a.

\section{SPOROVI KOJI SE ODNOSE NA BRODOVE KAO KOMPONENTA KAUZALNOGA KRITERIJA KOJOM SE DEFINIRA PLOVIDBENI SPOR}

\subsection{Terminologija i nomenklatura pomorskih objekata}

Brod je tehnička kategorija, ${ }^{25}$ ali isto tako i pravna kategorija te čak i gospodarska kategorija. To treba imati na umu kada se u praksi susreće s uporabom termina brod. Naime, dolazi ne samo u laičkom govoru, nego i u stručnom izražavanju do nepoželjnog miješanja raznih pojmova brod, a isto tako i pravnih pojmova brod, jahta, brodica, čamac.

Zbog toga prije detaljne analize značenja sintagme spor koji se odnosi na brod iz članka 34.b stavka 1. t. 6. ZPP-a te objašnjenja značenja pojma brod za potrebe te odredbe i određivanja stvarne nadležnosti, ukratko treba prikazati koja se terminologija rabi i koju nomenklaturu usvaja PZ pri razvrstavanju pojedinih pomorskih objekata. Pored toga treba objasniti i kakav utjecaj ima pravna klasifikacija brodova i drugih pomorskih objekata na stvarnu nadležnost.

PZ u članku 5. sadrži pravne definicije pojmova koje određuju značenje pojedinih izraza u smislu PZ-a, a one izravno utječu i na tumačenje članka 34.b stavka 1. t. 6. ZPP-a, znači relevantne su za određivanje dosega prve komponente kauzalnog kriterija.

Prema nomenklaturi PZ najširi pravni pojam je pomorski objekt, a podvrste toga šireg pojama su plovni objekt, plutajući objekt i nepomični odobalni objekt. ${ }^{26}$ S obzirom na temu ovog rada, relevantno je objasniti da su brod, kao i jahta i brodica, tipovi ili podvrste plovnih objekata, znači, spadaju u zajednički širi pojam plovni objekt (engl. vessel), koji je prema članku 5. stavku 1. t. 3. PZ-a definiran kao pomorski objekt namijenjen za plovidbu morem. Plovni objekt može biti brod, ratni brod, podmornica, jahta ili brodica. Pojam čamac danas se rabi samo u propisima koji uređuju unutarnju plovidbu. ${ }^{27}$

25 Brodovi se u tehničkom pogledu dijele prema konstrukciji koja ovisi o njihovoj namjeni.

26 Pomorski objekt jest objekt namijenjen za plovidbu morem (plovni objekt), ili objekt stalno privezan ili usidren na moru (plutajući objekt), odnosno objekt u potpunosti ili djelomično ukopan u morsko dno ili položen na morsko dno (nepomični odobalni objekt) (čl. 5. st. 1. t. 2. PZ-a). U čl. 5. PZ-a definirana je svaka od nabrojenih podvrsta pomorskog objekta.

27 Čl. 4. st. 17. Zakona o plovidbi i lukama unutarnjih voda (Narodne novine, br. 109/07, 132/07, $51 / 13,152 / 14)$ definira čamac kao plovilo namijenjeno za plovidbu unutarnjim vodama koje nije brod, plutajuće postrojenje ili skela, a čija duljina je veća od $2,5 \mathrm{~m}$ ili ukupne snage porivnih strojeva veće od $5 \mathrm{~kW}$. Pravilnik o čamcima (Narodne novine, br. 72/15 i 81/15) kao 
Pravni pojam broda definiran u članku 5. stavku 1. t. 4. PZ-a ima sljedeće značenje: «brod, osim ratnog broda jest plovni objekt namijenjen za plovidbu morem, čija je duljina veća od 12 metara, a bruto tonaža veća od 15, ili je ovlašten prevoziti više od 12 putnika. Brod može biti putnički, teretni, tehnički plovi objekt, ribarski, javni ili znanstvenoistraživački».

Prema nomenklaturi PZ-a tehnički plovni objekti su brodovi, iako izgledom često uopće ne sliče klasičnim brodovima. Tehnički plovni objekt jest brod, sa ili bez mehaničkog poriva koji je namijenjen za obavljanje tehničkih radova (bager, dizalica, jaružalo, pokretni odobalni objekt za istraživanje i eksploataciju podmorja i sl.) (članak 5. stavka 1. t. 12. PZ).

Za razliku od toga, brod u gradnji nije plovni objekt, niti brod u smislu PZ-a. Slijedom toga, kada je riječ o sporu iz ugovora o gradnji broda nije ispunjena prva komponenta kauzalnoga kriterija, jer se spor ne odnosi na brod, ali u vezi s takvim sporom bit će temeljem članka 34.b stavka 1. t. 6. ZPP-a nadležan trgovački sud, jer se na ugovor o gradnji broda primjenjuje plovidbeno pravo i to odredbe dijela sedmog, glava I., članci 430-441. PZ-a. Brod u gradnji jest gradnja broda od trenutka polaganja kobilice ili sličnog postupka gradnje do trenutka upisa u upisnik brodova (članak 5 . stavak 1. t. 29. PZ-a).

PZ u članku 5. stavku 1. t. 20. jahtu definira kao plovni objekt za sport i razonodu, neovisno koristi li se za osobne potrebe ili za gospodarsku djelatnost, a čija je duljina veća od 12 metara i koji je namijenjen za dulji boravak na moru, te koji je pored posade ovlašten prevoziti ne više od 12 putnika. Treba smatrati da i jahta kako je definirana u PZ-u ulazi u opseg pojma brod za potrebe članka 34.b stavka 1. t. 6. ZPP-a. Takav zaključak proizlazi iz navedene zakonske definicije jahte te također iz članka 2. stavka 1. PZ-a, koji propisuje da se odredbe PZ-a koje se odnose na brodove primjenjuju i na jahte. Međutim, treba istaknuti da povijesno komparativna analiza pojma jahte u hrvatskom zakonodavstvu pokazuje da se razlikuju pozitivno pravna definicija jahte od definicije jahte iz ZPUP-a i PZ-a 1994. Člankom 6. stavkom 1. t. 21. ZPUP-a bilo je propisano upravo to da jahta jest brod, za razliku od toga članak 5. stavak 1. t. 14. PZ iz 1994. jahtu definira kao brod ili brodicu. ${ }^{28}$ Stoga su različite definicije jahte u pozitivnom i ranijem domaćem zakonodavstvu vjerojatno još jedan od razloga neujednačenog pristupa u praksi.

PZ brodicu definira kao plovni objekt namijenjen za plovidbu morem koji nije brod ili jahta, čija je duljina veća od 2,5 metara ili ukupne snage porivnih strojeva

propis donesen na temelju tog zakona razvrstava čamce na podvrste (čamac za negospodarske namjene, čamac za gospodarske namjene, čamac za javne namjene, osobno plovilo na vodomlazni pogon, gliser, jedrilica, sportski čamac, čamac na vesla), vidjeti definicije čl. 2. Pravilnika o čamcima.

28 Spomenute odredbe ZPUP-a i PZ-a iz 1994. govorile su i o drukčijoj namjeni jahte u odnosu na njezinu namjenu prema pozitivnom zakonu. Bilo je propisano da jahta u neprivredne svrhe služi razonodi, sportu ili rekreaciji. Zbog komercijalizacije nautičkog turizma i njegovog formiranja kao posebne djelatnosti koja obuhvaća i kompleksno područje pravnog uređenja dopunjen je pojam jahte u PZ-u, na način da je dodano da namjena jahte može biti i gospodarska djelatnost. Danas se posebno intenzivno razvija, tzv. čarter djelatnost, pa se razmatra da se u PZ de lege ferenda uvede novi imenovani ugovor i to ugovor o najmu jahte ili brodice. 
veće od $5 \mathrm{~kW} .^{29}$

Uz to, hrvatsko pravo poznaje i podjelu jahti i brodica na određene podvrste te pojmove rekreacijsko plovilo i gliser, a njihove pravne definicije sadržane su u Pravilniku o brodicama i jahtama (u nastavku Pravilnik). ${ }^{30}$ Pravilnik rabi pojam plovilo, u smislu toga propisa plovilo znači bilo koje rekreacijsko plovilo ili osobno plovilo na vodomlazni pogon (čl. 3. st. 1. t. 24. Pravilnika).

Razvrstavanje jahti i brodica treba promatrati u specifičnom kontekstu koji uređuje Pravilnik, a koji se odnosi ponajprije na tehničke standarde koje trebaju ispunjavati te kategorije plovnih objekata (tehnički uvjeti za stavljanje na tržište plovila za sport i razonodu, ograničenja plovidbe, namjena, inspekcija, registracija, i dr.). Podjela jahti i brodica na podvrste, izravno ne utječe na odabir stvarno nadležnog suda kada su u pitanju jahte, međutim, može utjecati kada su u pitanju brodice. Znači, za odabir stvarno nadležnog suda, nije odlučna namjena jahte i pitanje koristi li se jahta za iznajmljivanje ili se ne koristi u gospodarske namjene. Uvijek kada je u pitanju jahta nadležan je trgovački sud jer se jahta u smislu članka 34.b stavka 1. t. 6. ZPP-a smatra brodom. Takav zaključak također proizlazi i iz članka 2. stavka 1. PZ-a, koji propisuje da se odredbe PZ-a koje se odnose na brodove primjenjuju i na jahte.

U domaćoj sudskoj praksi evidentirana je jedna starija sudska odluka u kojoj je sud izrazio stajalište da klasifikacija brodova i jahti na određene podvrste, konkretno prema njihovoj namjeni nije odlučna za izbor stvarno nadležnog suda jer zakon koji uređuje pitanja stvarne nadležnosti ne razlikuje brodove prema namjeni, već samo određuje da je za sporove u vezi s brodovima nadležan trgovački sud. ${ }^{31}$

Kod brodice nije ispunjena prva komponenta kauzalnog kriterija (spor se ne odnosi na brod), ali ako je riječ o brodici za gospodarske namjene mogu nastati

29 Uz to, u zakonskoj definiciji brodice navodi se da pojam brodica ne obuhvaća: plovila koja pripadaju drugom pomorskom objektu u svrhu prikupljanja, spašavanja ili obavljanja radova, plovila namijenjena isključivo za natjecanja, kanue, kajake, gondole i pedaline, daske za jedrenje i daske za jahanje na valovima (čl. 5. st. 1. t. 15. PZ.).

30 Pravilnik o brodicama i jahtama (Narodne novine, br. 27/05, 57/06, 80/07, 3/08, 18/09, 56/10, 97/12, 137/13 i 18/16, u nastavku Pravilnik), kao podzakonski propis donesen je na temelju čl. 1021. st. 3. PZ-a, usklađen je s Direktivom 2013/53/EU Europskoga Parlamenta i Vijeća od 20. studenoga 2013. o rekreacijskim plovilima i osobnim plovilima na vodomlazni pogon i o stavljanju izvan snage Direktive 94/25/EZ Europskoga Parlamenta i Vijeća od 16. lipnja 1994. o usklađivanju zakona i drugih propisa država članica u vezi s rekreacijskim plovilima (Službeni list Europske unije, L 354/90-131 od 28.12.2013. http://www.crs.hr/Portals/0/docs/ hrv/brodice_jahte/Direktiva\%202013_53_EU\%20hr.pdf stranica posjećena 1.12.2017. (u nastavku Direktiva 2013/53/EU od 20. studenoga 2013.).

31 U predmetu u kojem se spor odnosi na jahtu koja služi za razonodu nastao je sukob nadležnosti između OS u Supetru i OPS u Splitu. OPS u Splitu oglasio se stvarno nenadležnim i predmet ustupio OS u Supetru, koji je izazvao sukob nadležnosti. VSH, temeljeći svoju odluku na odredbi čl. 6. st. 1. toč. 21. ZPUP-a u obrazloženju odluke istaknuo je da se jahta koja služi za razonodu, sport i rekreaciju smatra brodom, pa je temeljem čl. 36. st. 1. t. c) Zakona o redovnim sudovima (Narodne novine, br. 5/77 i 27/88) za sporove u vezi s takvom vrstom broda stvarno nadležan okružni privredni sud. VSH je istaknuo da Zakon o redovnim sudovima ne razlikuje brodove prema namjeni, već samo određuje da je za sporove o brodovima nadležan privredni sud, pa budući da i jahta za razonodu spada pod pojam broda za sporove u vezi s jahtama stvarno je nadležan okružni privredni sud (odluka VSH broj Gr-415/1990 od 26. prosinca 1990.). 
sporovi na koje se primjenjuje plovidbeno pravo, pa je ispunjena treća komponenta kauzalnog kriterija, primjerice sporovi iz ugovora o prijevozu putnika ili stvari, ugovori o zakupu, ugovori o drugim pomorskim plovidbenim poslovima i sl. ${ }^{32}$

Definiranje pravnih pojmova pomorskih objekata vrlo je složeno i važno pitanje jer se posredno ili neposredno sve norme pomorskog prava odnose primarno na brodove, ali nerijetko i na druge plovne ili pomorske objekte. Pravni pojam brod vjerojatno je najčešće korišten pojam u pomorskim propisima, njega definiraju i gotovo sve konvencije pomorskog prava kojima se na međunarodnoj razini unificiraju pojedini segmenti pomorskog prava. Definicije variraju od jedne do druge međunarodne konvencije, a kada se još pribroje rješenja raznih nacionalnih propisa dobiva se širok spektar pojmova i njihovih definicija. ${ }^{33} \mathrm{O}$ tomu koliko je složen zadatak definiranja pravnih pojmova pojedinih pomorskih objekata te izrada pravne klasifikacije pomorskih objekata svjedoči i činjenica da je Međunarodni pomorski odbor (Comite Maritime International - CMI) osnovao radnu grupu koja se bavi pitanjem pravne nomenklature brodova i drugih pomorskih objekata. ${ }^{34}$ Radna skupina između ostalog istražuje i ima li u nacionalnim judikaturama sudskih odluka koje se odnose na tumačenje pravne klasifikacije brodova i drugih pomorskih objekata te postoje li u sudskoj praksi slučajevi različitih tumačenja definicija plovni objekt, brod i slično ili neusklađenih i proturječnih definicija u propisima koji su utjecali na sudske odluke. Smatramo da u hrvatskom zakonodavstvu nema neusklađenih i proturječnih definicija pojmova različitih tipova plovnih objekata ili još šire pomorskih objekata. Međutim, treba ukazati na važnost pravilne uporabe zakonskih pojmova i pravilnog tumačenja jasnih zakonskih definicija u sudskoj praksi. ${ }^{35}$ Sljedeći primjer pokazuje da sudovi ponekad ne koriste odgovarajuće nazive, a što bi moglo značiti da ne razumiju razlike među ovim pojmovima, to bi moglo rezultirati krivom primjenom prava, a to je neprihvatljivo. Bitno je respektirati isključivo pravne pojmove plovnih objekata (brod, jahta, brodica), a ne njihove nazive koji se rabe u kolokvijalnom govoru. VSRH ${ }^{36}$ je u odluci o sukobu stvarne nadležnosti između općinskog i trgovačkog suda, istaknuo sljedeće: ,... iz tužbe je vidljivo da se radi o sporu iz ugovora o kupoprodaji broda motorne jahte tipa Princess 286 ... jahta o kojoj se vodi spor ima duljinu 8m...". U ovom se slučaju, plovni objekt o kojem je riječ, pogrešno na jednom mjestu naziva brodom, a na drugom jahtom, jer je u konkretnom slučaju riječ o brodici. ${ }^{37}$

\subsection{Sporovi koji se odnose na brodove i jahte}

Upravo za potrebe određivanja stvarne nadležnosti treba dobro razjasniti što zakonodavac za potrebe članka 34.b stavka 1. t. 6. ZPP-a podrazumijeva pod

32 Opširnije infra t. 3.3. it. 5 .

33 SKORUPAN WOLFF i PADOVAN, op. cit., bilješka 7., str. 387.

34 CMI International Working Group on Vessel Nomenclature http://www.comitemaritime.org/ International-Working-Groups/0,2758,15832,00.html, stranica posjećena 27. 4. 2016.

35 SKORUPAN WOLFF i PADOVAN, op. cit., bilješka 7., str. 388.

36 VSRH, Gr 146/1998 od 1. 10. 1998.

37 Uporaba pogrešne terminologije u ovoj sudskoj odluci nije imala za posljedicu pogrešnu primjenu prava. Sud je odlučio da je za postupanje nadležan općinski sud (OS u Zadru). 
sintagmom „spor koji se odnosi na brod“ i to respektirajući: a) pravnu definiciju pojma brod iz PZ-a i b) tumačenje smisla i dosega odredbe članka 34.b stavka 1. t. 6. ZPP-a kojom se određuju komponente kauzalnoga kriterija za uspostavu stvarne nadležnosti trgovačkog suda.

Doslovno i isključivo jezično tumačenje prve komponente kauzalnoga kriterija iz članka 34.b stavka 1. t. 6. PZ-a «spor koji se odnosi na brod» eliminiralo bi sve druge plovne objekte ${ }^{38}$ koji nisu brodovi. Znači, doslovno i restriktivno tumačenje rezultiralo bi utvrđenjem da se pojmu brod ne bi moglo pridati drukčije, točnije šire značenje od onog koje taj pojam ima u navedenoj definiciji broda iz PZ-a. Tumačenje stiricto sensu pojma brod ne bi bilo u skladu sa značenjem, odnosno ciljevima odredbe članka 34.b stavka 1. t. 6. ZPP-a i protivilo bi se ratio legis odnosne odredbe. ${ }^{39}$

Značenje odredbe izvoditi isključivo iz njezinog teksta, ne upuštajući se u njezino tumačenje $\mathrm{u}$ širem smislu te utvrđivanje njezine svrhe bio bi pogrešan pristup. Tumačenje pravne norme u širem smislu, odnosno njezino tumačenje lato sensu posebice je nužno kad je sporno polje njezine primjene. Stoga, da bi se izbjegla ,primjena pravne odredbe protivno njezinom značenju i cilju, pri tumačenju pravne odredbe potrebno je koristiti se ne samo jezičnom već i drugim tehnikama tumačenja, kao što u teleološko i sistematsko tumačenje." “40

Teleološko i sistematsko tumačenje značenja sintagme «spor koji se odnosi na brod» pokazuje da se polje primjene članka 34.b stavka 1.t. 6. ZPP-a ne može odrediti isključivo jezičnim tumačenjem pojma brod kako ga definira članak 5. PZ-a, već da se pri određivanju značenja pojma brod za potrebe tumačenja članka 34.b stavka 1. t. 6. ZPP-a mora uzeti u obzir i:

- druga dva elementa - komponente kauzalnoga kriterija,

- međusobni odnos triju komponenti kauzalnoga kriterija te

- $\quad$ cilj i doseg članka 34.b stavka 1. t. 6. ZPP-a kao cjeline. ${ }^{41}$

Slijedom toga, za potrebe određivanja stvarne nadležnosti sudova, pojam brod treba shvatiti u širem smislu, točnije tako da se njime obuhvate svi plovni objekti koji se prema definicijama članka 5. PZ-a mogu smatrati brodom. Ovakvo je stajalište potvrđeno i u domaćoj pomorskopravnoj doktrini. ${ }^{42}$

U ovom smislu, brodom za potrebe članka 34.b stavka 1. t. 6. ZPP-a trebalo bi smatrati i tehnički plovni objekt jer se u gore citiranoj definiciji broda iz PZ-a navodi da brod može biti i tehnički plovni objekt. Također, i prema definiciji tehničkog plovnog objekta iz PZ-a, tehnički plovni objekt određen je kao brod. ${ }^{43}$

PZ klasificira brodove na više podvrsta: putnički brod, brzi putnički brod, teretni

38 Plovni objekt jest pomorski objekt namijenjen za plovidbu morem. Plovni objekt može biti brod, ratni brod, podmornica, jahta ili brodica (čl. 5. st. 1. t. 3. PZ-a).

39 SKORUPAN WOLFF i PADOVAN, op. cit., bilješka 7., str. 388.

40 Tomljenović, V., Tumačenje kolizijskih pravila međunarodnih konvencija - primjer tumačenja kolizijskih odredbi Haške konvencije o prometnim nezgodama, Zbornik Pravnog fakulteta $u$ Zagrebu, 62 (2012), br. 1-2, str. 101-152.

41 SKORUPAN WOLFF i PADOVAN, op. cit., bilješka 7., str. 388-389.

42 Tako ističe i STANKOVIĆ, op. cit., bilješka 12., str. 215, SKORUPAN WOLFF i PADOVAN, op. cit., bilješka 7., str. 389 i PADOVAN i SKORUPAN WOLFF, op. cit., bilješka 8., str. 261.

43 Vidjeti definiciju tehničkog plovnog objekta čl. 5. st. 1. t. 12. PZ-a i tumačenje supra t. 3. 1. 
brod, brzi teretni brod, tehnički plovni objekt, tegljač odnosno potiskivač, nuklearni brod, ribarski brod, javni brod, tanker za ulje, tanker za kemikalije, brod za ukapljene plinove, znanstveno istraživački brod. ${ }^{44}$ Sve njih treba obuhvatiti pojmom brod za potrebe članka 34.b stavka 1. t. 6. ZPP-a.

Aktualna sudska praksa potvrđuje stajalište da se prva komponenta kauzalnoga kriterija članka 34.b stavka 1. t. 6. ZPP-a odnosi i na jahte, točnije da su trgovački sudovi u parničnom postupku u prvom stupnju nadležni za suđenje u sporovima koji se odnose na jahte. U sporu u kojem tužitelj zahtijeva naknadu štete od štetnika koji je njegovu jahtu oštetio pri spuštanju u more, kao i od osiguravatelja temeljem ugovora o osiguranju, $\mathrm{VSRH}^{45}$ je $\mathrm{u}$ istaknuo da se jahta u smislu PZ-a smatra brodom, pa se u sporu koji se odnosi na jahtu primjenjuju pravila o postupku u trgovačkim sporovima temeljem odredbe članka 489. t. 2. ZPP-a, a za odlučivanje u ovom predmetu nadležan je trgovački sud. ${ }^{46}$

Ako se pojam jahta rabi u kolokvijalnom govoru ili gospodarskom smislu, može obuhvatiti i plovilo kraće od 12 metara. Takvo plovilo može biti plovilo velike vrijednosti koje po svim faktičnim karakteristikama osim po duljini ima obilježja jahte. Međutim za potrebe članka 34.b stavka 1. t. 6. ZPP-a treba biti relevantan pravni pojam jahte kako je definiran u PZ-u, pa se stoga plovilo kraće od 12 metara ne smatra jahtom, niti brodom. ${ }^{47}$

U opseg pojma jahte za potrebe članka 34.b stavka 1. t. 6. ZPP-a ušla bi i športska jahta isključivo namijenjena sudjelovanju na sportskim natjecanjima, a razvrstana prema klasama sportskih organizacija ili je izvan klase. Naravno i u ovom slučaju riječ je o plovnom objektu dužine najmanje $12 \mathrm{~m}$. Ako se radi o plovnom objektu kraćem od $12 \mathrm{~m}$, bit će riječ o športskoj brodici ${ }^{48}$ Kao što je prethodno istaknuto, Pravilnik razvrstava jahte na više podvrsta, ${ }^{49}$ ali odabir stvarno nadležnog suda nije relevantna vrsta odnosno namjena jahte, za sve sporove u vezi s jahtom nadležni su trgovački sudovi. ${ }^{50}$

U našem pozitivnom pravu javljaju se i pojmovi rekreacijsko plovilo i gliser. Iz definicije rekreacijskog plovila, koju sadrži Pravilnik mogu se ekstrahirati dva bitna elementa koji određuju njegovu definiciju. Prvi je da je riječ o plovilu bilo koje vrste, a drugi da je njegova duljina trupa od 2,5 do $24 \mathrm{~m} \cdot{ }^{51}$ To znači, da bi ono rekreacijsko plovilo koje je duže od $12 \mathrm{~m}$ ulazilo u pojam broda za potrebe članka 34.b stavka 1 . t. 6. ZPP-a. Takvo tumačenje, omogućuje i nalaže da se sva pravna pitanja i odnosi

44 Vidjeti definicije nabrojenih podvrsta brodova u čl. 5. PZ-a.

45 VSRH, Revt 90/2006 od 5. 9. 2007.

46 Vidjeti bilješku 31, odluka VSRH u predmetu: Gr-415/90 od 26. prosinca 1990. U ovom slučaju ne radi se o aktualnoj sudskoj praksi jer je primijenjen ZPUP.

47 Opširnije supra t. 3.1., vidjeti tekst uz bilješke 36. $i 37$.

48 Tako tumače i SKORUPAN WOLFF i PADOVAN, op. cit., bilješka 7., str. 390; vidjeti definiciju čl. 3. st. 1. t. 12. Pravilnika.

49 Pravilnik klasificira jahte, pa se razlikuju jahta za osobne potrebe i jahta za gospodarske namjene. Jahta za gospodarske namjene jest jahta namijenjena iznajmljivanju sa ili bez posade (čl. 3. st. 1. t. 5. Pravilnika), a jahta za osobne potrebe jest jahta koja se ne koristi u gospodarske namjene (čl. 3. st. 1. t. 6. Pravilnika).

50 Opširnije supra t. 3.1.

51 Vidjeti definiciju čl. 3. st. 1.t. 7. Pravilnika. 
koji se pojavljuju u kontekstu sporova koji se odnose na rekreacijska plovila duljine veće od 12 m rješavaju pred trgovačkim sudovima kao stvarno nadležnim sudovima. ${ }^{52}$

Slična je situacija i s gliserima. Pravilnik sadrži ambivalentnu definiciju glisera. Članak 3. stavak 1. t. 8. Pravilnika gliser definira kao brodicu ili jahtu koja pomoću mehaničkog porivnog uređaja klizi po površini mora. Pravilnik je zakonski akt donesen na temelju PZ-a, a to znači da je usklađen s njime. U tom slučaju definicija glisera određena Pravilnikom ne smije biti proturječna definiciji jahte i brodice iz PZa. Zbog toga treba smatrati da i gliser duljine veće od $12 \mathrm{~m}$ ulazi u pojam broda za potrebe članka 34.b stavka 1. t. 6. ZPP-a, točnije takav gliser smatra se jahtom. Gliser duljine veće od 12 metara podvrsta je jahte i koristi se u nautičkom turizmu, a može biti namijenjen iznajmljivanju ili se koristiti kao jahta za osobne potrebe u kojem slučaju se ne koristi u gospodarske namjene. Kao što je istaknuto, gliser po definiciji može biti i brodica, ako mu je duljina trupa 12 metara..$^{53}$

Prvom komponentom kauzalnoga kriterija članka 34.b stavka 1. t. 6. ZPP-a ne bi trebalo obuhvatiti ratni brod i plutajuće objekte. Članak 5. stavak 1. t. 4. PZ-a iz opće definicije broda isključuje ratni brod. ${ }^{54}$ Također, plutajući objekti ne bi ulazili u pojam brod jer su oni definirani kao pomorski objekti stalno privezani ili usidreni na moru, koji nisu namijenjeni za plovidbu (npr. plutajući dok, plutajuće skladište, plutajući restoran, plutajuća elektrana, pontonski most, pontonska marina i sl..) ${ }^{55} \mathrm{Uz}$ to, pojmom brod nisu obuhvaćene brodice i hidroavioni na vodi. ${ }^{56}$

Slijedom toga, za potrebe članka 34.b stavka 1. t. 6. ZPP-a brod uključuje:

a) brod kako je definiran u članku 5. stavku 1. t. 4. PZ-a, kao i sve prethodno nabrojane podvrste brodova osim ratnog broda posebno definirane u članku 5. PZ-a,

b) jahtu kao plovni objekt na koji se prema decidiranoj odredbi članka 2. stavka 1. PZ-a primjenjuju odredbe PZ-a koje se odnose na brodove. ${ }^{57}$

Prema aktualnoj sudskoj praksi brod je najvažnija poveznica za izbor trgovačkog suda kao stvarno nadležnog suda prema članku 34.b stavku 1. t. 6. ZPP-a. Analiza sudske prakse upućuje na zaključak da je za sudove okolnost da se radi o sporu koji se odnosi na brod u odnosu na druge dvije objektivne komponente kauzalnoga kriterija u puno bližem i važnijem odnosu koji dovodi do primjene članka 34.b stavka 1. t. 6 . ZPP-a, odnosno uspostave nadležnosti trgovačkog suda. ${ }^{58}$

Naime, prema aktualnoj sudskoj praksi do uspostave stvarne nadležnosti trgovačkog suda dolazi uvijek kada je u pitanju spor koji se odnosi na brod, neovisno

52 Tako tumače i SKORUPAN WOLFF i PADOVAN, op. cit., bilješka 7., str. 393.

53 Ibid; str. 393-394; o brodici opširnije infra t. 3.3.

54 Prema čl. 5. st. 1.t. 6. PZ-a hrvatski ratni brod jest plovni objekt, uključujući podmornicu, koji je pod zapovjedništvom pripadnika Oružanih snaga Republike Hrvatske, a čija je posada vojna, odnosno podvrgnuta vojnoj disciplini i koji je dužan isticati vanjske znakove raspoznavanja ratnih brodova hrvatske državne pripadnosti kad god je potrebno da svoje svojstvo učini poznatim.

55 Čl. 5. st. 1.t. 13. PZ-a

56 O pojmu brodica i o nadležnosti suda za sporove koji se odnose na brodice opširnije infra t. 3.3.

57 Tako tumače i SKORUPAN WOLFF i PADOVAN, op. cit., bilješka 7., str. 389.

58 Primjeri iz sudske prakse u vezi sa sporovima koji se odnose na brodice infra t. 3.3., tumačenje komponenti spor koji se odnosi na plovidbu na moru infra t. 4. i spor na koji se primjenjuje plovidbeno pravo infrat. 5 . 
o tomu je li istodobno riječ i o sporu koji se odnosi na plovidbu morem i primjenu plovidbenog prava. ${ }^{59} \mathrm{U}$ sudskoj praksi razmatrano je pitanje trebaju li za uspostavu nadležnosti trgovačkog suda na temelju članka 34.b stavka 1. t. 6. ZPP-a biti kumulativno ispunjene sve tri komponente kauzalnoga kriterija (brod + plovidba na moru + primjena plovidbenog prava). VSRH je svojim jasnim tumačenjem pridonio rasvjetljavanju ovog pitanja. Iznio je shvaćanje da je za uspostavljanje nadležnosti trgovačkog suda na temelju članka 34.b stavka 1. t. 6. ZPP-a dovoljno da se radi o sporu koji se odnosi na brod, a da nije nužno da se istodobno radi i o sporu koji se odnosi na plovidbu morem i/ili primjenu plovidbenog prava.

U sporu radi naknade štete zbog požara na brodu koji se u vrijeme štetnog događaja nalazio na navozu, TS u Splitu ocijenio je da nije stvarno nadležan, jer je u konkretnom slučaju brod samo predmet štete, znači, spor se odnosi na brod sam po sebi bez njegove veze s plovidbom i primjenom plovidbenog prava. VSRH ${ }^{60}$ nije prihvatio takvu argumentaciju i odlučujući o sukobu nadležnosti između općinskog i trgovačkog suda, odlučio je da je za postupanje u ovom predmetu stvarno nadležan trgovački sud. Zaključio je da se u ovom predmetu radi o sporu radi naknade štete koja se odnosi na brod, pa je u smislu odredbe članka 19. stavka 1. toč. 1b. Zakona o sudovima za suđenje nadležan trgovački sud. VSRH je istaknuo da je dovoljno da je ispunjena samo prva komponenta kauzalnoga kriterija (radi se o sporu koji se odnosi na brod), te da nije potrebno da su kumulativno ispunjene prva i druga komponenta kauzalnog kriterija, točnije ne mora istodobno biti riječ o sporu koji se odnosi na brod i plovidbu morem. Ovakav zaključak potvrđuje i odluka suda o sukobu nadležnosti u predmetu koji se odnosi na spor u vezi s kupoprodajom broda. VSRH ${ }^{61}$ je odlučio da je za postupanje u predmetu nadležan trgovački sud jer se spor odnosi na brod, iako se spor ne odnosi na plovidbu morem i na spor se ne primjenjuje plovidbeno pravo, već odredbe obveznog prava, konkretno, odredbe ZOO-a o kupoprodaji. Isto tako, i za suđenje u sporu radi isplate dijela zarade za korištenje broda, koji se nalazi u suvlasništvu stranka, nadležan je trgovački sud jer se radi o sporu koji se odnosi na brod. VSRH ${ }^{62}$ je istaknuo da nije relevantno to što se na spor ne primjenjuje plovidbeno pravo jer se spor odnosi na brod. U već spomenutom postupku ${ }^{63}$ u kojem je predmet spora naknada štete do koje je došlo zbog spuštanja tužiteljeve jahte u more, a na koji se ne primjenjuje plovidbeno pravo i koji se ne odnosi na plovidbu na moru VSRH ${ }^{64}$ je istaknuo kako je ovo spor koji se odnosi na brod, pa je iz tog razloga za postupanje u predmetu stvarno nadležan trgovački sud. ${ }^{65}$

Opisana sudska praksa utemeljena je na pravilnom tumačenju smisla članka 34.b stavka 1. t. 6. ZPP-a jer isključuje u praksi nepoželjnu mogućnost da se o pojedinim sporovima koji se odnose na brod, ali ne i na plovidbu morem i/ili na

59 To je potvrđeno i u istraživanju SKORUPAN WOLFF i PADOVAN, op. cit., bilješka 7., str. 404.

60 VSRH, Gr-679/1999 od 27. 9. 2000.

61 VSRH, Gr1-40/2010 od 19.3. 2010.

62 VSRH, Gr-511/1999 od 11. 10. 2000.

63 Vidjeti tekst uz bilješku 45.

64 VSRH, Revt 90/06 od 5.9.2007.

65 Vidjeti bilješku 31, odluka VSRH Gr 415/90 od 26. 12.1990. 
primjenu plovidbenog prava raspravlja i odlučuje na općinskim, a ne na trgovačkim sudovima. Kreiranjem pravila iz članka 34.b stavka 1. t. 6. ZPP-a htjelo se postići upravo takvu sudsku praksu. Drugim riječima, pravilnim tumačenjem važnosti i uloge prve komponente kauzalnoga kriterija i cilja odredbe članka 34.b stavka 1. t. 6. ZPP-a, postiže se učinak da za sporove koji se odnose na brodove ne postoji više stvarno nadležnih sudova već svi sporovi koji se odnose na brodove neovisno o predmetu spora ulaze u nadležnost trgovačkog suda.

Međutim, ako je brod samo mjesto na kojem se dogodio štetni događaj, a predmet spora i meritum pravne stvari se ne odnose na brod, neće biti nadležan trgovački sud. U sporu radi naknade štete u vezi sa štetnim događajem koji se dogodio na brodu stacioniranom u luci, a u kojem ozlijeđeni radnik koji je radio na ukrcaju tereta na brod potražuje naknadu štete od svog poslodavca, VSRH ${ }^{66}$ je odlučujući o sukobu nadležnosti između općinskog i trgovačkog suda zaključio da je za rješavanje spora u ovom predmetu stvarno nadležan općinski sud. U obrazloženju odluke VSRH je istaknuo da se ne vodi spor koji se odnosi na brod, točnije predmet spora nije u vezi s brodom i plovidbom morem, niti se na spor primjenjuje plovidbeno pravo. ${ }^{67}$

U predmetu u kojem tužitelj traži naknadu štete radi oštećenja ribarske mreže do kojeg je došlo kad je tuženikov brod propelerom zahvatio tužiteljevu ribarsku mrežu, VSRH $^{68}$ je odlučio da nije riječ o sporu za koji je nadležan trgovački sud. Prema tumačenju VSRH, ovaj spor se ne odnosi na brod, pored toga u pitanju je spor za naknadu štete koji nije reguliran pomorskopravnim propisima, znači na spor se ne primjenjuje plovidbeno pravo. Ova se odluka može izložiti kritici, naime smatramo da ne bi trebalo biti sporno da je riječ o sporu koji se odnosi na plovidbu na moru, jer se radi o izvanugovornoj odgovornosti za štetu koju je prouzročio brod u plovidbi, pa bi trebao biti nadležan trgovački sud jer je ispunjena druga komponenta kauzalnoga kriterija. ${ }^{69}$

Treba istaknuti da pri odlučivanju o stvarnoj nadležnosti sud nije vezan pravnom osnovom spora koju ističe tužitelj. U postupku u kojem tužitelj ističe da je predmet spora tražbina s osnova stjecanja bez osnove, okružni privredni sud oglasio se nenadležnim za postupanje. Istaknuo je da je o tražbini s osnova stjecanja bez osnove u smislu odredbe 85. Zakona o mjenici (NN, br. 53/91), nadležan za suđenje općinski sud. VSRH ${ }^{70}$ je po razmatranju ove pravne stvari, našao da je za suđenje u ovom sporu stvarno nadležan okružni privredni sud. Spor je proistekao iz ugovora o kupoprodaji broda, predmet spora je zahtjev tužitelja za isplatu neisplaćenog dijela kupoprodajne cijene broda, znači spor se odnosi na brod, pa zbog toga VSRH ovaj spor smatra pomorskim sporom i to bez obzira na to što tužitelj njegovu pravnu osnovu naziva stjecanjem bez osnove, odnosno tražbinom iz mjenice koju mu je izdao tuženik na ime naplate neisplaćene cijene broda. Identičan stav izražen je i u starijoj judikaturi. ${ }^{71}$

66 VSRH, Rev-923/99 od 1.7.2003.

67 Identično je sud odlučio i obrazložio svoju odluku i u predmetima VSRH, Gr 271/98 od 20.1.1999 i VSRH, Gr-537/97 od 30.6.1998.

68 VSRH, Gr-145/1991 od 16. 5. 1991.

69 Opširnije o sporu koji se odnosi na plovidbu na moru infra t. 4.

70 VSRH, Gr 24/93, od 18.2.1993.

71 U predmetu VSH, R-368/1985 od 19. 11. 1985., VSH je odlučio da je za odlučivanje u sporu iz 


\subsection{Sporovi koji se odnose na brodice}

Kao što je detaljno opisano, gramatičkim i teleološkim tumačenjem, može se zaključiti da sporovi koji se tiču brodica nisu obuhvaćeni prvom komponentom kauzalnoga kriterija odredbe članka 34.b stavka 1.t. 6. ZPP-a. Znači, nije sporno da se propis članka 34.b stavka 1. t. 6. ZPP-a odnosi samo na brodove u opsegu toga pojma i njegovu tumačenju opisanom supra. U protivnom, zakonodavac bi pri propisivanju prve komponente kauzalnog kriterija upotrijebio opći pojam, primjerice, plovni objekt koji bi uključivao i brodice. Ovako nema prostora za tumačenje, da se htjelo obuhvatiti sve, već samo brodove u opisanom opsegu toga pojma. ${ }^{72}$

Zakonodavac nije uključio brodice u doseg prve komponente kauzalnog kriterija jer se u vrijeme kreiranja postojećega koncepta stvarne nadležnosti, a to je bilo prije više od šezdeset godina smatralo da brodice kao mali plovni objekti nemaju veću materijalnu vrijednosti i gospodarski značaj, kao niti sporovi u vezi s tim plovnim objektima. Danas se više ne može reći da brodice imaju takve atribute, mnoge od njih su slične jahtama, imaju tehnički vrlo složene karakteristike i sofisticiranu elektroniku, hidrauliku i ostalu opremu. S pravne strane danas se u odnosu na brodice sklapaju ugovori istog sadržaja kao za jahte, pravna pitanja koja mogu nastati iz tih ugovora kao i izvanugovornih odnosa mogu biti pravno složena, a vrijednost predmeta spora također može biti visoka.

Pravni pojmovi brod i brodica iz PZ-a te rekreacijsko plovilo iz Pravilnika oslanjaju se na tehničku komponentu o njihovoj duljini, a duljina broda, jahte, brodice ili rekreacijskog plovila jest duljina utvrđena Tehničkim pravilima. ${ }^{73}$ To znači, da faktično duljina plovila određuje prvu komponentu kauzalnoga kriterija iz članka 34.b stavka 1. t. 6. ZPP-a te tako izravno utječe i na stvarnu nadležnost sudova. Jedna od posljedica takve koncepcije je da u prvu komponentu kauzalnoga kriterija ulazi, primjerice, spor u vezi s plovilom duljine $12,10 \mathrm{~m}$ jer je ono po definiciji brod ili jahta, a ne ulazi spor koji se odnosi na plovilo duljine $11,90 \mathrm{~m}$ jer je takvo polovilo po definiciji brodica, iako, npr. spomenuta brodica može biti puno skuplje i tehnički složenije plovilo i u vezi s njim mogu nastati sporovi veće vrijednosti te pravno složeniji sporovi. ${ }^{74}$ Taj je problem još izraženiji kada je u pitanju rekreacijsko plovilo. Ispunjena je prva komponenta kauzalnoga kriterija iz članka 34.b stavka 1. t. 6. ZPP-a, samo ako se radi o rekreacijskom plovilu duljine veće od $12 \mathrm{~m}$. U nautičkom turizmu koriste se plovila različite duljine, međutim faktično imaju istu namjenu, istu ulogu i vrše istu djelatnost. U vezi sa svim plovnim objektima koji se rabe $\mathrm{u}$ nautičkom turizmu neovisno o duljinu plovila mogu nastati raznoliki sporovi u vezi

ugovora o prodaji broda nadležan okružni privredni sud, prema BREŽANSKI, op. cit., bilješka 16., str. 1223 i 1225.

72 Takav zaključak potvrđen je i u istraživanju SKORUPAN WOLFF i PADOVAN, op. cit., bilješka 7., str. 390.

73 Čl. 5. st. 1.t. 5. PZ-a.

74 U nautičkom turizmu brodice kao i jahte imaju istu namjenu, a u odnosu na njih se sklapaju ugovori o vezu istog sadržaja, s istim pravima i obvezama marina i korisnika veza, primjenjuju se isti propisi o ugovornoj odgovornosti za štetu i isti opći uvjeti ugovora i slično. Tako objašnjavaju SKORUPAN WOLFF i PADOVAN, op. cit., bilješka 7., str. 392 i 419. 
s ugovornom odgovornosti iz ugovora o vezu te izvanugovorne odgovornosti luke nautičkog turizma. Stoga se danas čini diskutabilnim oslanjati na duljinu plovila kao element koji utječe na definiranje prve komponente kauzalnoga kriterija članka 34.b stavka 1. t. 6. ZPP-a. ${ }^{75}$

Nadalje, sve tri komponente kauzalnoga kriterija treba gledati kao cjelinu, a to znači ako nije ispunjena prva komponenta kauzalnoga kriterija, znači spor se ne odnosi na brod, treba razmotriti jesu li ispunjene druga i treća komponenta kauzalnoga kriterija.

Izgleda da je problem u tomu što su u sudskoj praksi brojni primjeri u kojima su sudovi respektirali samo prvu komponentu kauzalnoga kriterija i zbog toga zaključili da je stvarno nadležan općinski sud, upravo jer se spor odnosi na brodicu, a ne na brod ili jahtu. Znači, sudska praksa stala je na stanovište da je u sporovima koji se odnose na brodicu prikladnija uspostava stvarne nadležnosti općinskih sudova. ${ }^{76}$ To potvrđuje i starija sudska praksa. ${ }^{77}$ Međutim, smatramo da sudska praksa prema kojoj su za sve sporove u vezi s brodicom stvarno nadležni općinski sudovi nije dobro rješenje i ne odgovara suvremenim oblicima iskorištavanja brodica.

Razmatranje problema moguće je na dvije razine:

- Analizom odredbe članka 34.b stavka 1. t. 6. ZPP-a koja se kreće isključivo u okviru tumačenja postojeće odredbe. Ako se utvrdi da su potrebne određene korekcije u tumačenju ove odredbe, izložit ćemo i kreirat ćemo smjernice za njezino pravilno tumačenja u praksi.

- Razmatranjem pitanja treba li izmijeniti postojeći koncept stvarne nadležnosti te izvršiti inkluziju brodica u primjenu članka 34.b stavka 1. t. 6. ZPP-a te na koji način to postići izmjenama navedenoga kompetencijskog propisa ili izmjenama i dopunama PZ-a. ${ }^{78}$

Kada je riječ o izboru stvarno nadležnog suda za spor koji se odnosi na brodicu nužno je sagledati odnos triju komponenti kauzalnoga kriterija i razmotriti za svaki pojedini slučaj koja/koje komponente su ispunjene te ovisno o tomu donijeti odluku koji sud je stvarno nadležan u konkretnom sporu u vezi s brodicom.

75 Opširnije PADOVAN i SKORUPAN WOLFF, op. cit., bilješka 8., str. 262-263.

76 Vidjeti odluke u sljedećim predmetima: spor iz ugovora o najmu brodice (VSRH, Gr1-350/07 od 26.9.2007.); spor iz ugovora o kupoprodaji brodice (VSRH, Gr1-285/13 od 15.4.2013.); spor u vezi s naknadom štete na brodici (VSRH, Gr-151/1998 od 29.7.1998.); spor iz ugovora o kupoprodaji brodice (VSRH, Gr-146/98 od 1.10.1998.); spor za naknadu štete na jedrilici (brodici) koja je u trenutku štetnog događaja bila na vezu (VTS, Pž-1739/05 od 22.9.2006.); ovršni postupak na brodici (VSRH, Gr1-336/07 od 25.9.2007.; VSRH, Gr1-397/06 od 7.1.2007.; VSRH, Gr1-772/12 od 29.1.2013.; VSRH, Gr1-352/11 od 31.8.2011.; VSRH, Gr1-32/11 od 22.2.2011.; VSRH, Gr1-312/2010 od 23.9. 2010.).

77 VSH je odlučio da je nadležan općinski sud u sljedećim sporovima: u sporu u kojem se traži naknada štete za uništeni čamac (VSH, R-144/1981 od 10.6.1981); u sporu o prodaji čamca (VSH, R-118/1983 od 12.5.1983.); u sporu zbog neurednog ispunjenja ugovora o popravku čamca (VSH, R-27/81 od 25.3.1981.); u sporu o plutajućim objektima (VSH, IIRev-61/1982 od 16.6.1982 i VSH, R-368/1985 od 19.11.1985.), prema BREŽANSKI, op. cit., bilješka 16., str. 1223.

78 Ovaj problem razmatra se u posebnom radu u kojem se proučava koncept stvarne nadležnosti sudova u pomorskim sporovima de lege ferenda. 
U tom smislu nužno je razlikovati četiri moguće hipotetske situacije na koje se može odnositi spor u vezi s brodicom:

A) ne odnosi se na plovidbu morem i na spor se ne primjenjuje plovidbeno pravo;

B) odnosi se na plovidbu morem, ali se na spor ne primjenjuje plovidbeno pravo;

C) ne odnosi se na plovidbu morem, ali se na spor primjenjuje plovidbeno pravo;

D) odnosi se na plovidbu morem i na spor se primjenjuje plovidbeno pravo.

Ako se radi o hipotetskoj situaciji A), znači ako se spor odnosi na brodicu, ali se ne odnosi na plovidbu morem i na spor se ne primjenjuje plovidbeno pravo moguće je složiti se sa stajalištem da je prema pozitivnopravnom uređenju stvarne nadležnosti za takve sporove uvijek nadležan općinski sud.

Primjeri sporova koji prema pozitivnopravnom uređenju članka 34.b stavka 1. t. 6. ZPP-a i aktualnoj sudskoj praksi ostaju izvan nadležnosti trgovačkog suda su sporovi $\mathrm{u}$ vezi s kupoprodajom brodice i sporovi u vezi s ovrhom na brodici. Spor u vezi s kupoprodajom brodice nije obuhvaćen prvom komponentom kauzalnoga kriterija, dakle, ne radi se o brodu, uz to, nisu ispunjene druge dvije komponente kauzalnoga kriterija, spor se ne odnosi na plovidbu morem i na njega se ne primjenjuje plovidbeno pravo. Znači, spor ne proizlazi izravno iz pomorske plovidbene djelatnosti, niti iz gospodarskog iskorištavanja brodice. U postupku treba primijeniti pravila obveznog prava jer spor proizlazi iz obveznopravnog odnosa - ugovora o kupoprodaji, a taj obveznopravni odnos nije reguliran PZ-om, znači, ne dolazi do primjene plovidbeno pravo.

PZ kao lex specialis propisuje da se ovrha i osiguranje na plovnom objektu koji se u smislu članka 5. PZ-a ne smatra brodom provodi prema Ovršnom zakonu (čl. 841. st. 3. PZ-a). Znači, u slučaju ovrhe na brodici ne primjenjuje se plovidbeno pravo, točnije, odredbe PZ-a o ovrsi i osiguranju na brodu i teretu. Također članak 841. stavak 6. PZ-a propisuje da ovrhu i osiguranje na brodu i teretu na brodu određuju i provode trgovački sudovi nadležni za pomorske sporove, argumentum a contrario ovrhu i osiguranje na plovnim objektima koji se u smislu PZ-a ne smatraju brodom provode općinski sudovi. Aktualna sudska praksa potvrđuje takvo stajalište.

$\mathrm{VSRH}^{79}$ je odlučivao o sukobu nadležnosti između općinskog i trgovačkog sud $\mathrm{u}$ predmetu u kojem je ovrhovoditelj podnio prijedlog za ovrhu radi naplate novčane tražbine na brodici ovršenika na kojoj je uknjiženo pravo zaloga na temelju solemniziranog ugovora o kreditu kao ovršne isprave. Općinski sud oglasio se stvarno nenadležnim pozivom na odredbu članka 33. a) stavka 2. t. 3. Ovršnog zakona (u nastavku OZ) prema kojoj trgovački sudovi određuju ovrhu iz članka 252. a) stavka 2. OZ-a iz njihove stvarne nadležnosti. U svojoj odluci općinski sud je istaknuo da je predmet ovrhe brodica na kojoj je uknjižena hipoteka u upisniku pomorskih i trgovačkih brodova, pa se po stajalištu OS u Rijeci primjenjuje plovidbeno pravo (PZ). TS u Rijeci otklonio je svoju nadležnost pozivom na odredbu PZ-a, kojom je određeno da se odredbe dijela deset PZ-a (ovrha i osiguranje na brodu i teretu) ne

79 VSRH, broj Gr1 336/07 od 25.9.2007. 
odnose na postupak ovrhe na brodicama. VSRH je zaključio da okolnost što je na predmetnom plovilu (brodici), a na temelju rješenja Lučke kapetanije, pozivom na članak 204. stavak 1. PZ-a obavljen upis uknjižbe ugovorne hipoteke koja je upisana na teretnom listu C, uloška Glavne knjige Hrvatskog upisnika pomorskih trgovačkih brodova, ne utječe na stvarnu nadležnost suda za provođenje ovrhe. Članak 841. stavak 6. PZ-a kao lex specialis izričito je propisano da ovrhu i osiguranje na brodu i teretu određuju i provode trgovački sudovi nadležni za pomorske sporove. Nadalje, VSRH je istaknuo da činjenicom upisa ugovorne hipoteke na brodici u upisnik pomorskih trgovačkih brodova, predmetna brodica ne gubi svoj status brodice, a niti je izričitom odredbom propisano u PZ-u da bi se postupak ovrhe i osiguranja na brodu i teretu odnosio i na postupak ovrhe na brodicama. Štoviše, suprotno od toga, prema odredbi citirane odredbe članka 841. stavka 3. PZ-a ovrha i osiguranje na plovnom objektu koji se u smislu članka 5. PZ-a ne smatra brodom provodi se prema Ovršnom zakonu, a prema odredbi članka 841. stavka 6. PZ-a ovrhu i osiguranje na brodu i teretu određuju i provode trgovački sudovi nadležni za pomorske sporove. Budući da je odredbom članka 33. a) stavka 1. OZ-a propisano da su općinski sudovi stvarno nadležni određivati ovrhu, osim ako rješavanje tih predmeta nije izrijekom povjereno drugom sudu, tijelu i osobi, a u ovom slučaju je zakonom (PZ) izrijekom trgovačkim sudovima povjerena ovrha samo na brodu, a i ne i na brodici, VSRH je odlučio da je stvarno nadležan općinski sud. ${ }^{80}$

U sporovima koji se odnose na hipotetsku situaciju A), a prethodno su opisani, sudska praksa je utemeljena na zakonu, znači pravo je pravilno primijenjeno i točno su interpretirane sve tri komponente kauzalnog kriterija.

O hipotetskoj situaciji B) radi se ako se spor odnosi na brodicu i na plovidbu morem, ali se na spor ne primjenjuje plovidbeno pravo. Primjerice može biti riječ

80 Slično kao i u prethodno izloženom primjeru, OS u Puli oglasio se nenadležnim za postupanje u predmetu u kojem je predlagatelj osiguranja protiv protivnika osiguranja zatražio određivanje privremene mjere zaustavljanja i zabrane raspolaganja brodicom upisanom u očevidniku brodica. TS u Rijeci, kojem je predmet ustupljen nije prihvatio nadležnost pozivom na odredbe čl. 841. st. 6. i čl. 5. st. 15. PZ-a, kao i odredbu čl. 16. st. 2. Zakona o sudovima, jer je smatrao da je za odlučivanje nadležan općinski sud. VSRH, Gr1-397/06 od 7.1.2007. odlučio je da je za suđenje u ovom predmetu stvarno nadležan općinski sud, a svoju odluku temelji na činjenici da je odredbom čl. 5. t. 15. PZ-a propisano da je brodica plovni objekt namijenjen za plovidbu morem koji nije brod ili jahta, čija je duljina veća od 2,5 $\mathrm{m}$ ili ukupna snaga porivnih strojeva veća od $5 \mathrm{KW}$, a odredbom čl. 841. st. 3. istog zakona propisano je da se ovrha i osiguranje na plovnom objektu koji se u smislu odredaba čl. 5. istog zakona ne smatra brodom provodi po ovršnom zakonu, čl. 841. st. 6. PZ-a propisano je da ovrhu i osiguranje na brodu i teretu na brodu određuju i provode trgovački sudovi nadležni za pomorske sporove. Iz izvatka očevidnika brodica Lučke kapetanije Pula razvidno je da je predmetni plovni objekt jedrilica s ugrađenim motorom Volvo. Iz toga proizlazi da se radi o brodici, a ne o brodu za čiju ovrhu i osiguranje bi bio nadležan trgovački sud. VSRH je zaključio da se nadležnost općinskog suda za postupanje u ovom predmetu temelji na odredbi čl. 18. st. 2. Zakona o sudovima (Narodne novine, broj: 150/05), kojom je propisano da općinski sudovi rješavaju u svim predmetima iz čl. 3. st. 2. navedenog zakona koji nisu stavljeni u djelokrug nekog drugog suda ili javnog bilježnika. Identične odluke donio je VSRH odlučujući o sukobu stvarne nadležnosti između općinskih i trgovačkih sudova i u postupcima Gr1-772/12 od 29.1.2013; Gr1-352/11 od 31.8.2011; Gr132/11 od 22.2.2011; Gr1-312/10 od 23.9.2010. 
o sporovima nastalim iz ugovora o najmu brodice, ugovora o vezu brodice ${ }^{81}$ ili sporovima u vezi s izvanugovornom odgovornosti za štetu na brodici, a na koje se odnose primjenjuju pravila ZOO-a, a ne PZ-a.

U postupku u kojem je tužitelj podnio općinskom sudu tužbu radi naknade štete iz ugovora o najmu plovila (tzv. charter yahting yahte B.), tvrdeći da je kao najmoprimac pretrpio štetu zbog nemogućnosti korištenja tog plovnog objekta u razdoblju od šest dana, s time da je najam bio ugovoren u trajanju od 14 dana, općinski sud se oglasio stvarno nenadležnim, pozivom na odredbu članka 34.b stavka 1. t. 6. ZPP-a, navodeći da je riječ o sporu koji se odnosi na brod i plovidbu na moru. Trgovački sud izazvao je sukob nadležnosti navodeći da je stvarno nadležan općinski sud upravo na temelju odredbe članka 34.b stavka 1. t. 6. ZPP-a u vezi s člankom 5. stavkom 1. t. 4, 15. i 20. PZ-a. VSRH ${ }^{82}$ je utvrdio da se radi o sporu iz ugovora o najmu plovnog objekta duljine manje od 12 metara, a to znači da se ne radi o brodu, već o brodici. Iz tog razloga odlučio je da je za suđenje u sporu radi naknade štete iz ugovora o najmu brodice stvarno nadležan općinski sud.

TS u Rijeci ${ }^{83}$ oglasio se stvarno nenadležnim za suđenje u sporu u kojem se tužbeni zahtjev za naknadu štete temelji na izvanugovornoj odgovornosti marine za štetu na jedrilici koja po svojim karakteristikama nije brod u smislu odredbe članka 5. stavka 1. t. 4. PZ-a, jer je dugačka 11,49 m, ima bruto tonažu manju od 15 i nije ovlaštena prevoziti više od 12 putnika. Unatoč tomu što tužitelj navodi da se radi o pomorskom sporu, TS u Rijeci spor nije ocijenio pomorskim sporom jer je našao da šteta nije nastala na brodu nego na brodici, da se ne radi o šteti nastaloj pri plovidbi na moru te u rješavanju spora nema elemenata za primjenu bilo koje odredbe plovidbenog prava. VTS $^{84}$ je prihvatio stajalište prvostupanjskog suda i istaknuo da je u ovom postupku nadležan općinski sud.

U oba slučaja radi se o tipičnim pomorskim pravnim stvarima. U prvom slučaju spor je nastao iz ugovora o najmu plovila. ${ }^{85}$ Ugovor o najmu plovila jest neimenovani ugovor, ${ }^{86}$ znači nije ugovor uređen PZ-om na koji se primjenjuje plovidbeno pravo. Međutim, spor nastao iz ugovora o najmu plovila svakako bi trebalo smatrati plovidbenim sporom u smislu članka 34.b stavka 1. t. 6. ZPP-a, jer je to spor koji se odnosi na plovidbu morem. U drugom slučaju je riječ o izvanugovornoj odgovornosti za štetu marine na plovilu. Iako se i u ovom slučaju ne primjenjuje plovidbeno pravo i on bi se trebalo smatrati sporom koji se odnosi na plovidbu morem. Nije opravdano da navedeni sporovi koji se odnose na brodicu i plovidbu morem izmiču iz nadležnosti

81 U tijeku je noveliranje PZ-a, a kao vrlo važna i dobrodošla dopuna PZ-a, predlaže se uređenje ugovora o najmu jahte ili brodice i ugovora o vezu kao novih imenovanih ugovora u hrvatskom pravu. Ako prijedlozi izmjena i dopuna PZ-a budu usvojeni, u tom slučaju sporovi iz ugovora o najmu jahte ili brodice i sporovi iz ugovora o vezu postat će sporovi na koje se primjenjuje plovidbeno pravo, pa će biti ispunjena treća komponenta kauzalnoga kriterija.

82 VSRH, Gr1 350/07 od 26. 9. 2007.

83 TS u Rijeci, P-2279/03 od 17. 1. 2005.

84 VTS, Pž-1739/05 od 22. 9. 2006.

85 U vezi s ugovorom o najmu plovila vidjeti rad Petrinović, R., Perkušić, A., Mandić, N., Ugovor o najmu jahte i brodice, Zbornik radova Pravnog fakulteta u Splitu, god. 45 (2008), br. 4, str. 863-884.

86 Vidjeti bilješku 81. 
trgovačkih sudova samo jer se radi o brodici, a ne o brodu. Prema postojećem normativnom ustroju stvarne nadležnosti i pravilnom tumačenju druge komponente kauzalnoga kriterija (spor koji se odnosi na plovidbu na moru) za navedene sporove bi primjenom članka 34.b stavka 1. t. 6. ZPP-a trebali biti nadležni trgovački sudovi. Ovi primjeri pokazuju da su potrebne određene korekcije u sudskom tumačenju ove odredbe kompetencijskog propisa i to ponajprije druge komponente kauzalnog kriterija (spor koji se odnosi na plovidbu na moru). ${ }^{87}$

Prema hipotetskoj situaciji C), riječ je o sporu u vezi s brodicom koji se ne odnosi na plovidbu morem, ali se na spor primjenjuje plovidbeno pravo, za takav bi spor primjenom članka 34.b stavka 1. t. 6. ZPP-a trebao biti nadležan trgovački sud. O ovoj hipotetskoj situaciji će se raditi ako se spor odnosi na ugovor o gradnji brodice jer je PZ-om propisano da se odredbe PZ-a o ugovoru o gradnji broda primjenjuju i na ugovor o gradnji brodice. ${ }^{88}$ Evidentirana je jedna starija sudska odluka u kojoj je sud odlučio da je za postupanje u sporu o neurednom ispunjenju ugovora o popravku čamca nadležan općinski sud. ${ }^{89}$ Iz opisanih razloga takvu sudsku praksu bi trebalo korigirati. U prilog tomu govori i zaključak autora Pallue i Jakaše, ${ }^{90}$ koji su još 1960. godine istaknuli: ,ako se radi o čamcu u vezi s primjenom pomorskog prava, tada će spor spadati pod pojam pomorskog spora, pa će biti nadležni sudovi koji su tamo navedeni“", pri tome misle na nekadašnje okružne privredne sudove.

Ako se radi o hipotetskoj situaciji pod D), znači ako se spor odnosi na brodicu i na plovidbu morem te se na spor primjenjuje plovidbeno pravo, za takav bi spor temeljem članka 34.b stavka 1. t. 6. ZPP-a trebao biti nadležan trgovački sud. Naime, osim toga što je ispunjena druga komponenta kauzalnoga kriterija (spor se odnosi na plovidbu na moru) ispunjena je i treća komponenta kauzalnoga kriterija (na spor se primjenjuje plovidbeno pravo). O primjeni plovidbenog prava, točnije PZ-a na brodice govori članak 2. stavak 2. PZ-a, kojim je određeno da se odredbe PZ-a koje se odnose na brodove primjenjuju i na brodice, samo ako je to PZ-om izričito predviđeno. Efektivno, odredbe PZ-a koje se odnose na brodove i jahte, a ne odnose se na brodice svode se na odredbe o pravu vlasništva (PZ, čl. 208. i dalje, osim čl. 214. st. 1.) $)^{91}$ te na ovrhu i osiguranje na brodu i teretu (PZ, čl. 841. i dalje). U preostalom dijelu materije uređene PZ-om predviđa se odgovarajuća primjena odredbi o brodovima i jahtama i na brodice (npr. založna prava, brodar i opće ograničenje odgovornosti brodara, ugovori o gradnji, preinaci i popravku broda, ugovori o iskorištavanju pomorskih brodova, ugovori o pomorskom osiguranju, sudar, spašavanje, zajednička havarija, izvanugovorna odgovornost brodara, vađenje i uklanjanje podrtina, mjerodavno pravo i nadležnost sudova, pomorski prekršaji) ili se propisuju posebne odredbe za brodice (npr. sposobnost brodice i jahte za plovidbu, upis i brisanje brodice) ${ }^{92}$ Treba

87 Tumačenje dosega druge komponente kauzalnoga kriterija «spor koji se odnosi na plovidbu morem», opširnije infra t. 4.

88 Čl. 430. st. 3. PZ-a.

89 VSH, R-27/81 od 25.3.1981.

90 PALLUA i JAKAŠA, op. cit., bilješka 9., str. 266.

91 PZ, čl. 214. st. 1. predviđa da se pravo vlasništva i druga stvarna prava na brodu, jahti ili brodici mogu steći, prenijeti, ograničiti i ukinuti jedino upisom u odgovarajući upisnik ili očevidnik.

92 O primjeni plovidbenog prava kao komponenti kauzalnoga kriterija opširnije infra t. 5 . 
napomenuti da kada je riječ o primjeni odredbi glave II, dijela sedmog PZ-a Ugovori $o$ iskorištavanju pomorskih brodova one se po prirodi stvari primjenjuju samo na brodice za gospodarske namjene. ${ }^{93}$ Svi ugovori o iskorištavanju brodova prema našem pozitivnom pravu su naplatni poslovi, pa se stoga takvi poslovi ne bi mogli ugovoriti za iskorištavanje brodica za osobne potrebe i javnih brodica jer je po definiciji njihova namjena korištenje u negospodarske namjene. ${ }^{94}$

Kao što je detaljno opisano, gramatičkim i teleološkim tumačenjem može se zaključiti da sporovi koji se tiču brodica nisu obuhvaćeni prvom objektivnom komponentom kauzalnog kriterija. Međutim, kao što je istaknuto, pogrešno je zaključiti da ako nije ispunjena prva pretpostavka - prva objektivna komponenta kauzalnoga kriterija nema uvjeta za primjenu članka 34.b stavka 1. t. 6. ZPP-a. Ako su ispunjene druge dvije komponente kauzalnoga kriterija nema razloga za to da ne dođe do primjene članak $34 . b$ stavak 1. t. 6. ZPP-a. Izgleda da je problem u tome što sudovi ponekad krivo tumače vezu triju komponenti kauzalnoga kriterija, odnosno ne daju istu važnost prvoj i ostalim dvjema komponentama kauzalnoga kriterija.

Tri komponente kauzalnoga kriterija vrlo se često ne preklapaju, ali se međusobno nadopunjuju. Zakon ravnopravno nabraja sve tri komponente, pa ako se tako razmatra problem primjene članka 34.b stavka 1. t. 6. ZPP-a, i ako se respektiraju sve tri komponente kauzalnoga kriterija, svi sporovi u kojima je zastupljena jedna od njih su plovidbeni sporovi za koje je temeljem članka 34.b stavka 1. t. 6. ZPP-a nadležan trgovački sud.

Za razliku od hipotetske situacije A) na koju se ne primjenjuje odredba članka 34.b stavka 1. t. 6. ZPP-a, u odnosu na druge tri hipotetske situacije pod B), C) i D) pravilno tumačenje odnosa triju komponenti kauzalnoga kriterija omogućuje primjenu u postojećoj formulaciji odredbe članka 34.b stavka 1. t. 6. ZPP-a. Smatramo da u svim sporovima koji se mogu svrstati pod hipotetske situacije B), C) i D), primjena odredbe članka 34.b stavka 1. t. 6. ZPP-a je opravdana i legitimna. Znači, ako je riječ o sporovima koji ulaze pod hipotetske situacije B), C) i D) do promjene u sudskoj praksi moglo bi doći određenim korekcijama u tumačenju članka 34.b stavka 1. t. 6 . ZPP-a.

\section{SPOROVI KOJI SE ODNOSE NA PLOVIDBU NA MORU I UNUTARNJIM VODAMA KAO KOMPONENTA KAUZALNOGA KRITERIJA KOJOM SE DEFINIRA PLOVIDBENI SPOR} odrediti:

U cilju egzaktne primjene odredbe članka 34.b stavka 1. t. 6. ZPP-a važno je

93 Tako tumače i Milošević Pujo, B., Petrinović, R., Pomorsko pravo za jahte i brodice, Pomorski fakultet u Splitu, Split, 2008., str. 106.

94 Iznimka je slučaj ako je brodica tegljeni objekt prema ugovoru o tegljenju. PZ u odredbi koja definira ugovor o tegljenju govori o brodu tegljaču i tegljenju ili potiskivanju broda ili drugog objekta (čl. 634. st. 1. PZ-a), a u čl. 637. govori se o tegljenju plovnog objekta (označila autorica). Brodica jest plovni objekt, pa nesporno proizlazi da se i odredbe PZ-a o tegljenju i potiskivanju primjenjuju i na brodice. 
a) Za koje se djelatnosti odnosno pravne poslove koji se odvijaju u pomorstvu smatra da se odnose na plovidbu na moru, a time koji sporovi proizašli iz tih djelatnosti i pravnih poslova se za potrebe članka 34.b stavka 1. t. 6. ZPP-a smatraju sporovima koji se odnose na plovidbu na moru. Također, za koje se sporove u vezi s izvanugovornom odgovornosti može reći da su sporovi koji se odnose na plovidbu na moru.

b) Koja je uloga u pozitivnopravnom smislu i koji je aktualni doseg u primjeni komponente sporovi koji se odnose na plovidbu na moru na utvrđivanje stvarne nadležnosti prema članku 34.b stavku 1. t. 6. ZPP-a. Drugim riječima, u kojoj mjeri (uz aktualni doseg u primjeni) komponenta kauzalnoga kriterija sporovi koji se odnose na plovidbu na moru utječe na utvrđivanje stvarne nadležnosti.

Ponajprije treba istaknuti da se sintagma plovidba na moru i unutarnjim vodama odnosi na pomorsku plovidbu, znači plovidbu koja se obavlja na moru i rijekama hrvatskoga Jadranskog sliva do granice do koje su one plovne s morske strane te na unutarnju plovidbu, znači plovidbu koja se obavlja na rijekama, kanalima i jezerima. U nastavku ovog rada, radi kratkoće u pisanju koristimo samo pojam plovidba na moru, a njime obuhvaćamo cjelovitu sintagmu sporovi koji se odnose na plovidbu na moru i unutarnjim vodama.

Pravna definicija pojma plovidba na moru ne postoji, pa je ovaj pojam predmet tumačenja sudske prakse. Činjenica da ne postoji zakonska definicija ovog pojma kao i posebnost formulacije ove komponente rezultira nužnošću tumačenja pojmova koje ona sadrži. U domaćoj pomorskopravnoj teoriji pod pojmom plovidbe podrazumijeva se kretanje plovnog sredstva vodenim medijem. ${ }^{95}$ Smatra se da je pomorska plovidba svako gibanje morskim prostorom uz uporabu sredstava koja se koriste silom uzgona. Pojam plovidbe u tom bi smislu obuhvatio, primjerice, i kretanje teglenice bez pogona, dok, naprotiv, ne bi obuhvatio plivanje. ${ }^{96}$

Slijedom toga, sporovi u vezi s plovidbom na moru jesu oni koji se odnose na bilo koji pravni odnos u kojem plovidba služi kao sredstvo određenoj svrsi koja se realizira uz pomoć plovidbe. Kod, tzv. klasičnih pomorskih sporova, a to su sporovi na koje se primjenjuje plovidbeno pravo, u praksi u pravilu nema dvojbi oko toga je li riječ o sporovima koji se odnose na plovidbu na moru, jer se kod njih redovito radi o tomu da je predmet spora koji čini sadržaj spora u vezi s plovidbom na moru. Znači, u sporove koji se odnose na plovidbu na moru ubrajali bi se svi sporovi nastali iz ugovornih odnosa uređenih PZ-om, jer se svi oni odvijaju plovidbom ili su u svezi s plovidbom.${ }^{97}$ To su svi sporovi nastali iz ugovora o iskorištavanju pomorskih brodova,

95 Tako ističe Jakaša, B., Udžbenik plovidbenog prava, Narodne novine, Zagreb, 1979., str. 1.

96 Tako smatra STANKOVIĆ, op. cit., bilješka 12., str. 215.

97 Iznimka je spor nastao iz ugovora o gradnji broda, međutim, i u ovom slučaju nije isključeno da u vezi s ugovorom o gradnji broda može doći do spora koji se odnosi na plovidbu na moru. Naime, funkcionalna povezanost plovidbe na moru s meritumom spora nastalog iz ugovora o gradnji broda može postojati ako dođe do spora koji je u neposrednoj vezi s pokusnom vožnjom broda u gradnji. Pravilnikom o uvjetima i načinu obavljanja pokusne plovidbe (Narodne novine, br. 10/2008) propisuju se uvjeti i način obavljanja pokusne plovidbe i broda u gradnji. Pokusna plovidba u smislu ovoga Pravilnika jest plovidba broda u gradnji od isplovljavanja do uplovljavanja broda u luku. 
znači ugovora o pomorskom plovidbenom poslu (ugovor o prijevozu stvari morem, ugovor o prijevozu putnika morem, ugovor o tegljenju, odnosno potiskivanju morem te ugovori koji se odnose na druge pomorske plovidbene poslove) i ugovora o zakupu broda.

Važno je istaknuti da pojam plovidbe za ovu svrhu ne bi trebalo ograničavati samo na nautičke djelatnosti, već njime valja obuhvatiti i sve komercijalne djelatnosti koje obavljaju brodovi. ${ }^{98}$ Znači, ovdje spadaju, primjerice sporovi u vezi s vozarinom, gubitkom, oštećenjem tereta, smrti i tjelesnih ozljeda putnika, ukrcajem, iskrcajem putnika ili tereta i sl. Uz to, u tipične pomorskopravne stvari (sporove) koji se odnose na plovidbu na moru ubrajaju se i sporovi nastali iz ugovora o spašavanju, vađenju i uklanjanju podrtina $\mathrm{i}$ potonulih stvari $^{99}$ te sporovi nastali $\mathrm{u}$ vezi sa sudarom $\mathrm{i}$ zajedničkom havarijom. Također, ovdje spadaju i svi sporovi u vezi s izvanugovornom odgovornosti za štetu vlasnika broda i brodara, na koje se primjenjuje plovidbeno pravo (odredbe čl. 808. do 823. PZ-a). ${ }^{100}$

Šrok je krug poslova, ali i faktičnih životnih situacija koje se mogu odvijati $\mathrm{u}$ pomorstvu. S razvojem tehnologije, prometa, intelektualnih usluga, uslužnih djelatnosti te novih vrsta plovila za razonodu, neizbježno se širi krug aktivnosti i poslova koji se odnose na plovidbu na moru. Zbog toga se pojam spor koji se odnosi na plovidbu na moru nužno mora široko interpretirati.

Osim gore nabrojenih treba smatrati da su sporovi koji se odnose na plovidbu na moru i svi drugi sporovi u kojima je predmet spora neraskidivo vezan i neodvojiv od plovidbe morem. Konkretno, radi se o sporovima koji se odnose na neimenovane ugovore, kao što su ugovor o vezu u moru i ugovor o najmu jahte ili brodice.

Sudska praksa komponenti spor koji se odnosi na plovidbu na moru ne pridaje odgovarajuću pažnju u kontekstu primjene članka 34.b stavka 1. t. 6. ZPP-a. U praksi u pravilu dolazi do uspostavljanja nadležnosti trgovačkog suda ako se spor odnosi na brod, iako se istodobno taj spor ne odnosi na plovidbu na moru. ${ }^{101}$ Međutim, u suprotnom slučaju, znači ako se spor odnosi na plovidbu na moru, a ne i na brod, aktualna sudska praksa nije jedinstvena i ujednačena. U nekim predmetima odlučivali

98 Takvo stajalište podupire i STANKOVIĆ, op. cit., bilješka 12., str. 215.

99 Primjerice, ako se vodi spor u vezi s nagradom za vađenje potonule brodice prva komponenta kauzalnoga kriterija neće biti ispunjena (ne radi se o brodu), ali treća komponenta kauzalnoga kriterija će biti ispunjena, jer se primjenjuju odredbe PZ-a o vađenju podrtina. Najčešće se radi o tomu da je ispunjena i druga komponenta (spor se odnosi na plovidbu na moru), jer se vađenje podrtine u pravilu odvija pomoću niza nautičkih i tehničkih akcija u moru.

100 Prva komponenta kauzalnoga kriterija neće biti ispunjena, a druge dvije hoće, ako se spor odnosi na naknadu štete zbog ozljede kupača nanesene gliserom duljine manje od $12 \mathrm{~m}$. Takav se gliser smatra brodicom, a spor se odnosi na plovidbu na moru i na njega se primjenjuje plovidbeno pravo. Također, u sporu o odgovornosti za štetu pričinjenu udarom ratnog broda u plutajući objekt ne bi bila ispunjena prva komponenta kauzalnoga kriterija, ali ispunjena su druga i treća komponenta kauzalnoga kriterija. Ratni brod i plutajući objekt ne smatraju se brodovima, ali se odredbe PZ-a koje uređuju izvanugovornu odgovornost brodara za oštećenje obale ili plutajući objekt izrijekom primjenjuju na ratne brodove. Također je ispunjen i drugi kriterij jer se spor odnosi na plovidbu na moru.

101 Vidjeti tekst uz bilješke 45, 61 i 70. 
su općinski sudovi, a u nekima trgovački. ${ }^{102}$ U praksi nerijetko dolazi do ustaljivanja stvarne nadležnosti. Riječ je o situaciji ako tuženik ne uloži prigovor stvarne nenadležnosti, a sud kojem je podnesena tužba se po službenoj dužnosti ne oglasi nenadležnim. ${ }^{103}$

Prisutno je shvaćanje sudova da okolnost da se radi o sporu u vezi s plovidbom na moru nije dostatna da bi postojala stvarna nadležnost trgovačkog suda. Drugim riječima, okolnost da je ispunjena druga komponenta kauzalnoga kriterija (radi se o sporu koji se odnosi na plovidbu morem) ne dovodi do iste posljedice do koje dovodi činjenica da je ispunjena prva komponenta kauzalnoga kriterija (radi se o sporu koji se odnosi na brod).

U sporu radi naknade štete iz ugovora o najmu plovila, u kojem tužitelj potražuje naknadu štete zbog nemogućnosti korištenja plovila u razdoblju za koje je najam bio ugovoren $\mathrm{VSRH}^{104}$ je odlučujući o sukobu nadležnosti zaključio da je nadležan općinski sud jer se radi o plovnom objektu duljine manje od 12 metara. ${ }^{105}$ Ugovor o najmu konzumira se, točnije ispunjava se pomoću plovidbe na moru. Kod ugovora o najmu plovila plovidba služi svrsi koja se ugovorom želi postići, a ugovor se može realizirati samo uz pomoć plovidbe morem. Cilj koji ugovorne strane žele postići sklapanjem tog ugovora je upravo najam plovila za plovidbu morem. Njegov je bitan sastojak uporaba jahte ili brodice za plovidbu. Zbog toga bi trebalo smatrati da je $u$ sporu nastalom iz ugovora o najmu plovila ispunjena druga komponenta kauzalnog kriterija.

U već spomenutom predmetu ${ }^{106} \mathrm{u}$ kojem tužitelj traži naknadu štete radi oštećenja ribarske mreže do kojeg je došlo kad je tuženikov brod propelerom zahvatio tužiteljevu ribarsku mrežu, VSRH ${ }^{107}$ je odlučio da nije riječ o sporu za koji je nadležan trgovački sud. Prema tumačenju VSRH-a, ovaj se spor ne odnosi na brod, pored toga u pitanju je spor za naknadu štete koji nije reguliran pomorskopravnim propisima, znači na spor se ne primjenjuje plovidbeno pravo. Ovo je, svakako, primjer spora koji se odnosi na plovidbu na moru, a sud se o toj okolnosti, odnosno toj komponenti kauzalnoga kriterija nije uopće očitovao. Smatramo da je spor čiji se meritum odnosi

102 Primjerice, OS u Rovinju odlučivao je u predmetu P-178/07 koji se odnosi na naknadu štete za više plovila koja su u trenutku štetnog događaja bila na vezu u marini, a do štete je došlo zbog požara koji je zahvatio nekoliko jahti na vezu. U vezi s istim štetnim događajem vodio se spor i pred OS u Opatiji P-524/07. Isto tako OS u Zadru P-2829/03 te ŽS u Zadru Gž-2465/10 i VSRH- 2333/10 odlučivali su u sporu iz ugovora o vezu i ugovora o ostavi broda. OS u Zagrebu Pn-7330/97 i ŽS u Zagrebu Gžn-2484/12 odlučivali su u sporu radi naknade štete iz ugovora o ostavi broda kojim se tuženi obvezao preuzeti brod na čuvanje i održavanje. Za razliku od toga u sporu radi naknade štete na brodici te isplate s osnova nemogućnosti korištenja brodice odlučivao je TS u Rijeci P-2590/94.

103 U povodu prigovora tuženika o stvarnoj nenadležnosti, sud se može oglasiti stvarno nenadležnim, samo ako je tuženik taj prigovor podnio najkasnije do upuštanja u raspravljanje o glavnoj stvari (čl. 17. st. 2. ZPP-a). Također, sud se može po službenoj dužnosti oglasiti stvarno nenadležnim najkasnije do upuštanja tuženika u raspravljanje o glavnoj stvari (čl. 17. st. 1. ZPP-a).

104 VSRH, Gr1 350/07 od 26. 9. 2007.

105 Opširnije opisana sudska odluka u tekstu uz bilješku 82.

106 Vidjeti tekst uz bilješku 68 i 69.

107 VSRH, Gr-145/1991 od 16. 5. 1991. 
na odgovornost za štetu koju je prouzročio brod u plovidbi, spor u vezi s plovidbom na moru.

Isto tako, u već spomenutom sporu radi isplate dijela zarade za korištenje broda, koji se nalazi u suvlasništvu stranka, ${ }^{108} \mathrm{VSRH}^{109}$ je odlučio da je za suđenje u sporu nadležan trgovački sud jer se radi o sporu koji se odnosi na brod. VSRH je istaknuo da nije važno to što se na spor ne primjenjuje plovidbeno pravo, jer se spor odnosi na brod. Međutim, nije se očitovao na okolnost da je i ovo spor koji se odnosi na plovidbu na moru jer se brod koristi na način da obavlja određenu djelatnost koja se može vršiti jedino plovidbom morem, pa je i ta okolnost relevantna za uspostavu nadležnosti trgovačkog suda.

U sporu u kojem se tužbeni zahtjev za naknadu štete temelji na izvanugovornoj odgovornosti marine za štetu na jedrilici koja se u trenutku štetnog događaja nalazila na vezu u marini, a koja po svojim karakteristikama nije jahta u smislu odredbe članka 5. stavka 1. t. 20. PZ-a, jer je dugačka 11,49 m, ima bruto tonažu manju od 15 i nije ovlaštena prevoziti više od 12 putnika TS u Rijeci ${ }^{110}$ oglasio se stvarno nenadležnim za suđenje. Zaključio je da šteta nije nastala na brodu nego na brodici, da se ne radi o šteti nastaloj pri plovidbi na moru niti se u rješenju spora primjenjuje plovidbeno pravo. $\mathrm{VTS}^{111}$ je prihvatio stajalište prvostupanjskog suda te je decidirano naveo da u ovom postupku ne nalazi elemenata za primjenu bilo koje odredbe plovidbenog prava u rješavanju spora, da se spor ne odnosi na brod, nego na jedrilicu koja je prema svojim karakteristikama brodica u smislu PZ-a, te da se ne radi o sporu nastalom iz plovidbe na moru. Smatramo da je pogrešna ocjena suda da predmetni spor nije spor koji se odnosi na plovidbu na moru. To što se plovilo u trenutku štetnog događaja nije nalazilo u plovidbi u doslovnom smislu riječi, ali se nalazilo na vezu u moru, ne znači da se kao što je prethodno opisano takav spor ne smatra sporom koji se odnosi na plovidbu na moru. ${ }^{112}$ Naime, sve aktivnosti u vezi s ugovorom o vezu plovila u moru, kao što su vezivanje, sidrenje, boravak na vezu, uplovljavanje, isplovljavanje te druge koje se odvijaju u moru treba smatrati da su u vezi s plovidbom na moru. Znači, druga je komponenta kauzalnoga kriterija ispunjena, točnije spor se može smatrati sporom koji je u vezi s plovidbom na moru.

U kontekstu članka 34.b stavka 1. t. 6. ZPP-a pojam plovidba na moru ne bi trebalo tumačiti doslovno. Isključivo jezično tumačenje odredbe može rezultirati rješenjem koje se protivi njezinu značenju i cilju. Tekstualna jasnoća pravne odredbe ne bi trebala isključivati korištenje drugih tehnika tumačenja, pogotovo logično i sistematsko tumačenje. Jezično tumačenje je nužno za razumijevanje pravne norme, ali ne i dovoljno sredstvo za njeno razumijevanje. Što znače pojedini izrazi iz normativnih odredaba, to se spoznaje tek primjenom drugih pravila tumačenja, a na kraju krajeva ciljnim tumačenjem koje je odlučujuće. ${ }^{113}$

108 Vidjeti tekst uz bilješku 62.

109 VSRH, Gr-511/1999 od 11. 10. 2000.

110 TS u Rijeci, P-2279/03 od 17. siječnja 2005.

111 TS u Rijeci, Pž-1739/05 od 22. rujna 2006.

112 Posebno o problemu stvarne nadležnosti u sporovima iz ugovora o vezu vidjeti SKORUPAN WOLFF i PADOVAN, op. cit., bilješka 7.

113 Visković, N., Teorija države i prava, Centar za dopisno obrazovanje, Birotehnika, Zagreb, 
Takvim tumačenjem granice procjene radi li se o sporu na koji se primjenjuje članak 34.b stavak 1. t. 6. ZPP-a bile bi postavljene šire nego čistim i jedino jezičnim tumačenjem zakonskoga teksta spor koji se odnosi na plovidbu na moru. Teleološkim tumačenjem može se utvrditi da je cilj zakonodavca drugom komponentom kauzalnoga kriterija obuhvatiti osim sporova koji su nastali u vezi s kretanjem plovnog objekta uz korištenje sile uzgona i sporove nastale plovidbom morem u širem smislu. ${ }^{114}$

Prethodno izložena sudska praksa implicira zaključak da ako se spor ne odnosi na brod nego na brodicu, ali se odnosi na plovidbu morem element plovidba na moru prema aktualnoj sudskoj praksi prestaje biti odlučna i relevantna komponenta za uspostavu nadležnosti trgovačkog suda. To znači, da sudovi ne daju jednaku važnost tumačenju kriterija plovidba na moru i brod. Posljedica toga je da je faktično u praksi prema odredbi članka 34.b stavka 1. t. 6. ZPP-a stvarna nadležnost trgovačkog suda determinirana primarno okolnošću radi li se o sporu koji se odnosi na brod i/ ili primjenu plovidbenog prava. Prema takvoj sudskoj praksi, komponenta spor koji se odnosi na plovidbu na moru ima relativan učinak u praksi na uspostavu stvarne nadležnosti prema članku 34.b stavku 1. t. 6. ZPP-a. Takva sudska praksa dovodi do toga da iz nadležnosti trgovačkog suda izmiču svi oni sporovi koji se odnose na plovidbu na moru ali koji se istodobno ne odnose na brod i na koji se ne primjenjuje plovidbeno pravo. Za rješavanje tih sporova stranke trebaju pravnu zaštitu tražiti pred općinskim sudom. Iz toga se može zaključiti da aktualna sudska praksa u tumačenju ove komponente kauzalnog kriterija ne zadovoljava one ciljeve i potrebe koji se žele postići pravnopolitičkim opredjeljenjem da trgovački sudovi odlučuju u sporovima koji se odnose na plovidbu na moru. Zalažemo se za to da se takva sudska praksa promijeni.

Prethodno opisani primjeri iz sudske prakse dokazuju da je nužno postojanje druge komponente kauzalnog kriterija u zakonu te da ova komponenta kauzalnog kriterija treba imati veliku ulogu i praktičnu važnost. Svrha ove komponente kauzalnog kriterija je da se pokriju oni slučajevi u praksi (sporovi) u kojima nisu ispunjene prva i treća komponenta kauzalnog kriterija te da se time što veći broj pomorskih stvari (sporova) uključi u nadležnost trgovačkih sudova, a to je i cilj članka 34.b stavka 1. t. 6. ZPP-a.

Smatramo da bi trgovački sudovi trebali biti nadležni za sporove nastale iz pravnog prometa u kojem sudjeluju subjekti koji imaju sporove koji se odnose na plovidbu na moru ali se ne odnose na brodove i/ili primjenu plovidbenog prava. Plovidba na moru je možda najtipičnija komponenta plovidbenog spora, pa nije opravdano da sporovi koji se odnose na plovidbu na moru izmiču iz nadležnosti trgovačkih sudova. Postojeći propis članka 34.b stavka 1. t. 6. ZPP-a omogućuje ekstenzivno tumačenje dosega komponente spor koji se odnosi na plovidbu na moru.

Navođenje karakteristike sporovi u vezi s plovidbom na moru, argumentum a contrario znači da navedenom komponentom nisu obuhvaćeni sporovi koji nisu u svezi s plovidbom na moru u dosegu toga pojma kako je navedeno. ${ }^{115}$ Predmet spora

2006., str. 248-249.

114 SKORUPAN WOLFF i PADOVAN, op. cit., bilješka 7., str. 395-396.

115 Međutim, kao što je više puta istaknuto to ne znači da i za te sporove neće biti nadležan 
koji čini sadržaj spora neće biti u vezi s plovidbom na moru primjerice, u slučaju spora u vezi kupoprodaje broda, ${ }^{116}$ spora nastalog u vezi s dokovanjem broda, ${ }^{117}$ spora u vezi s gradnjom broda ${ }^{118}$ te spora iz ugovora o suhom vezu. Riječ je o pravnim odnosima u kojima faktični, odnosno materijalni predmet spora ne ulazi u opseg pojma spor $u$ vezi s plovidbom na moru.

Posebno treba istaknuti i naglasiti da je za primjenu članka 34.b stavka 1. t. 6. ZPP-a bitna funkcionalna povezanost plovidbe na moru s meritumom spora. U tom kontekstu odlučna je narav tražbine i njezin odnos prema komponenti spor koji se odnosi na plovidbu na moru. Činjenica da se štetni događaj dogodio za vrijeme plovidbe na moru ne znači da je ispunjena druga komponenta kauzalnoga kriterija. To dokazuje i sljedeći primjer iz sudske prakse. Tužiteljica je protiv svog poslodavca podnijela tužbu radi naknade štete zbog ozljeda zadobivenih na radu. Do ozljeđivanja tužiteljice je došlo tijekom prijevoza remorkerom od novosagrađenog broda koji se nalazio na pokusnoj vožnji, a koji je izgradio tuženi (tužiteljičin poslodavac). VSRH ${ }^{119}$ je zaključio da je u ovom sporu riječ o radnom sporu radi naknade štete nastale u vezi s tužiteljičinim radom kod tuženika, a ne o sporu koji se odnosi na brod i plovidbu na moru. Znači, iako se štetni događaj dogodio tijekom plovidbe morem, meritum spora nije neposredno vezan za brod i plovidbu morem, već radnopravni status i ozljedu tužiteljice na radu.

U sporu radi naknade štete zbog uništenja jahte do kojeg je došlo na prostoru predviđenom za spuštanje plovila u more postupao je i odlučivao trgovački sud te u drugom stupnju VTS. Štetni događaj dogodio se za vrijeme manevra prebacivanja jahte s kopna u more, u trenutku podizanja s obale i spuštanja u more kada je grana auto dizalice pala na jahtu i uništila. ${ }^{120} \mathrm{U}$ tom slučaju ne postoji funkcionalna povezanost merituma spora na koji se odnosi tužbeni zahtjev s plovidbom na moru. Nadležan je trgovački sud jer se radi o sporu koji se odnosi na brod (jahtu). Isto tako, ako je plovilo na suhom vezu u marini, tada se niti ekstenzivnim tumačenjem sintagme spor koji se

trgovački sud. Tri komponente kauzalnoga kriterija se ne preklapaju, one se nadopunjuju, pa ako nije ispunjena druga komponenta (spor se odnosi na plovidbu na moru), a ispunjena je prava (spor se odnosi na brod) i/ili treća komponenta (na spor se primjenjuje plovidbeno pravo) za postupanje i odlučivanje u sporu bit će nadležan trgovački sud.

116 Vidjeti tekst uz bilješke 61, 70 i 71.

117 Dokovanjem se brod izvlači izvan doticaja morske vode u svrhu pregleda ili održavanja podvodnog dijela trupa broda i brodske opreme koja se nalazi uronjena u more. Brod može ići na dokovanje iz više razloga zbog pregleda, održavanja, remonta i popravka ili preinake. Ako se dokovanje broda obavlja na temelju samostalnog ugovora onda se na dokovanje primjenjuju odredbe PZ-a koje reguliraju druge pomorske plovidbene poslove (čl. 440. st. 2. PZ-a), a spor nastao u vezi s tim ugovorom treba smatrati plovidbenim sporom jer se na njega primjenjuje plovidbeno pravo, ali to nije spor u vezi s plovidbom morem.

118 Iako spor nastao iz ugovora o gradnji broda načelo nije spor u vezi s plovidbom na moru, može postojati iznimka koja ne potvrđuje to pravilo. O tome kada je ispunjena druga komponenta kauzalnoga kriterija (spor koji se odnosi na plovidbu na moru) u sporu nastalom iz ugovora o gradnji broda, opširnije infra bilješka 97.

119 VSRH, Gr 258/93 od 26.8.1993.

120 VSRH Revt 121/07 od 19.11.2008. Opširniji prikaz presude: Skorupan Wolff, V., Odgovornost za štetu nanesenu uporabom autodizalice - osigurateljni aspekti, Poredbeno pomorsko pravo Comparative Maritime Law, god. 52 (2013), br. 167., str. 203-205. 
odnosi na plovidbu na moru ne može zaključiti da je spor u vezi plovila na suhom vezu spor u vezi plovidbe na moru. Ako su plovila na suhom vezu jahta ili brod doći će do primjene članak 34.b stavak 1. t. 6. ZPP-a i za postupanje i odlučivanje u sporu bit će nadležan trgovački sud jer je ispunjena prva komponenta kauzalnog kriterija. Međutim, ako je riječ o brodici na suhom vezu tada nije ispunjena niti jedna od tri komponente i ne dolazi do primjene članak 34.b stavak 1. t. 6. ZPP-a. ${ }^{121}$

\section{PRIMJENA PLOVIDBENOG PRAVA KAO KOMPONENTA KAUZALNOG KRITERIJA KOJOM SE DEFINIRA PLOVIDBENI SPOR}

Primjena plovidbenog prava određena je kao jedna od posebnih komponenti kauzalnoga kriterija iz članka 34.b stavka 1. t. 6. ZPP-a kojom se definira plovidbeni spor. Time varijabla primjena plovidbenog prava bitno i vrlo izravno utječe na koncept stvarne nadležnosti iz članka 34.b stavka 1. t. 6. ZPP-a. Isticanje prava koje se na spor primjenjuje i vezivanje spora na koji se primjenjuje plovidbeno pravo uz nadležnost trgovačkog suda jasno pokazuje cilj te norme, a on je da se primjena plovidbenog prava odvija pred trgovačkim sudovima kao specijaliziranim sudovima za tu granu prava. Učinak koji se postiže takvim zakonskim rješenjem izbjegavanje je jurisdikcije više sudova različite vrste na sporove na koje se primjenjuje plovidbeno pravo. ${ }^{122}$

Kao i precizno definiranje dviju prethodno opisanih komponenti i definiranje dosega komponente spor na koji se primjenjuje plovidbeno pravo iznimno je važno za određivanje stvarne nadležnosti sudova. Treća komponenta kauzalnoga kriterija ispunjena je ako se na pravni odnos iz kojeg je nastao spor, odnosno pravno pitanje $\mathrm{u}$ sporu primjenjuje plovidbeno pravo. Pojam plovidbenog prava nije definiran u PZ$\mathrm{u}$, niti u nekom drugom domaćem propisu, pa se sudovi primjenjujući ovu odredbu, često suočavaju s potrebom utvrđivanja značenja pojma plovidbeno pravo. ${ }^{123}$

Pomorsko pravo je jedinstveno i autonomno. Unatoč tomu, podijeliti ga na materiju koja je uređena PZ-om (sigurnost plovidbe koja uključuje i odredbe o pomorcima, točnije posadi broda, upis i brisanje brodova, jahti i brodica, stvarna prava, odredbe o brodaru, ugovore, pomorske nesreće, ovrhu i osiguranje na brodu i teretu, mjerodavno pravo i nadležnost sudova u Republici Hrvatskoj, pomorske prekršaje) značilo bi pojednostavniti stvar. Zakonodavac zahtijeva da sudovi pri tumačenju ove komponente kauzalnoga kriterija, znači utvrđivanju njezinog značenja i dosega primjene moraju promatrati i njezin odnos prema odgovarajućim odredbama međunarodnih ugovora koje obvezuju Republiku Hrvatsku, a kojima se uređuju pitanja plovidbenog prava. Također, relevantno je cjelokupno domaće pozitivno pravo

121 Drugačija je situacija ako je riječ o brodici na suhom vezu na kojoj se obavljaju popravci, bojanje, servisiranje motora ili opreme ili neki sličan posao koji ulazi u poslove održavanja, a koji se vrše na temelju ugovora o popravku brodice. U sporu između vlasnika brodice i brodopopravljača iz ugovora o popravku brodice neće biti upitna nadležnost trgovačkog suda temeljem čl. 34.b st. 1. t. 6. ZPP-a, jer će biti riječ o sporu na koji se primjenjuje plovidbeno pravo, znači ispunjena je treća komponenta kauzalnoga kriterija.

122 SKORUPAN WOLFF i PADOVAN, op. cit., bilješka 7., str. 399-340.

123 Ibid, str. 400. 
koje osim zakona uključuje i brojne podzakonske akte. ${ }^{124}$

Kauzalna komponenta je ovdje postavljena šire nego u prva dva slučaja kauzalnih komponenti iz članka 34.b. stavka 1. t. 6. ZPP-a. Dovoljno je da se radi o sporu iz bilo kojeg pomorskog odnosa na koji se primjenjuje bilo koji propis koji se smatra pomorskopravnim propisom (plovidbenim propisom). Nije nužno da je to PZ kao krovni domaći propis, kojim se kodificira pomorsko pravo.

U praktične svrhe, a u kontekstu tumačenja članka 34.b stavka 1. t. 6. ZPP-a valja uzeti da plovidbeno pravo predstavlja sve što je sadržano u PZ-u, kao i u svim drugim zakonima i podzakonskim aktima koji uređuju pitanja plovidbe. ${ }^{125}$ Pod plovidbenim pravom smatra se skup pravnih normi kojima se reguliraju specifični odnosi koji se pojavljuju u vezi s plovidbom. ${ }^{126}$ Drugim riječima, sve norme koje se neposredno ili posredno odnose na plovidbu morem mogu se smatrati plovidbenim pravom. ${ }^{127}$

Širina pojma plovidbeno pravo, ali i brojnost propisa te raznolikost sporova koji se odnose na pomorske objekte u nekim slučajevima otežava davanje jedinstvenog odgovora na pitanje radi li se o sporu na koji se primjenjuje plovidbeno pravo. Zbog toga se egzemplifikativnim nabrajanjem vrsta ili primjera sporova pobliže određuje pojam spor na koji se primjenjuje plovidbeno pravo.

Treba istaknuti i to da je plovidbeno pravo dinamična disciplina, kontinuirano se pojavljuju novi propisi, a pravna pitanja koja su danas aktualna u ovom području prije nekoliko desetljeća nisu bila prisutna ili nisu bila zrela za pravno normiranje, primjerice pravno uređenje koje se odnosi na plovila za razonodu i ugovore $u$ nautičkom turizmu (ugovor o najmu jahte ili brodice i ugovor o vezu). ${ }^{128}$ Stoga dolazi do širenja nadležnosti trgovačkih sudova i na one sporove na koje se primjenjuju odredbe novih propisa koji se mogu smatrati propisima plovidbenog prava.

Odgovor na pitanje što je predmet ugovora iz kojeg je nastao spor ili ako se radi o izvanugovornoj odgovornosti, što je predmet spora, utječe na zaključak točnije, predstavlja kriterij za prosudbu primjenjuje li se na spor plovidbeno pravo.

U postupku koji je trajao preko trideset godina, između ostalog bilo je sporno pitanje koji sud je stvarno nadležan za odlučivanje u sporu. Općinski i županijski sud ocijenili su da se ne primjenjuje plovidbeno pravo u sporu u kojem tužitelj zahtijeva naknadu štete zbog oštećenja njegove brodice, opreme i pribora, nastale naletom glisera tuženika na tužiteljevu brodicu. Sudovi temelje svoju odluku na činjenici da se odredbe ZPUP-a, koje se odnose na brodove primjenjuju na čamce, ${ }^{129}$ samo ako je to tim zakonom izričito predviđeno, a budući da tužitelj zahtijeva naknadu štete na njegovom čamcu, opremi i priboru na takav spor se ne primjenjuje plovidbeno pravo. Protiv pravomoćne drugostupanjske odluke reviziju su podnijele obje stranke,

124 Sistematizirani popis međunarodnih ugovora i zakona i podzakonskih akata iz područja pomorskog prava vidjeti: Republika Hrvatska, Ministarstvo mora, turizma, prometa i razvitka: Međunarodni i nacionalni propisi iz područja pomorskog prava, Pomorski glasnik, Zagreb, 2007.

125 Opseg pojma plovidbeno pravo tako tumači i STANKOVIĆ, op. cit., bilješka 12., str. 215-216.

126 Tako JAKAŠA, op. cit., bilješka 95., str. 1.

127 Tako SKORUPAN WOLFF i PADOVAN, op. cit., bilješka 7., str. 400.

128 Vidjeti bilješku 81.

129 ZPUP je umjesto pojma brodice koristio pojam čamac, riječ je o istoj vrsti plovnog objekta. 
a tuženik je u reviziji istaknuo prigovor stvarne nenadležnosti nižestupanjskih sudova, koji su odlučivali u postupku, jer smatra da je za suđenje u ovom sporu stvarno nadležan okružni privredni sud. VSRH ${ }^{130}$ je ocijenio da je pravilno pravno shvaćanje tuženika da se na ovaj spor trebaju primijeniti odredbe plovidbenog prava. Štetni događaj se dogodio 6. kolovoza 1977. godine, pa se na spor kao mjerodavno materijalno pravo treba primijeniti odredbe zakona koje su bile na snazi u vrijeme štetnog događaja, a to je Zakon o naknadi štete zbog sudara brodova ${ }^{131}$ koji je važio do 31. prosinca 1977. godine i propisivao da se odredbe tog zakona primjenjuju na naknadu štete što su je brod, osobe na brodu ili stvari na brodu pretrpjeli zbog sudara brodova, a brod je u smislu toga zakona svaki polovni objekt bez obzira na svrhu kojoj služi, (identično zakonsko rješenje sadržavao je i ZPUP te PZ iz 1994., kao i PZ iz 2004.). VSRH je posebno naglasio da se u okvir plovidbenog prava pored drugih propisa svakako treba uključiti i odredbe navedenog Zakona o naknadi štete zbog sudara brodova.

VSRH je zauzeo stajalište da su sporovi u vezi s plaćanjem naknade za korištenje veza sporovi na koje se primjenjuje plovidbeno pravo. ${ }^{132}$ To potvrđuje i starija sudska praksa. U sporu iz 1978. godine $\mathrm{VSH}^{133}$ je rješavajući sukob nadležnosti između općinskog i okružnog privrednog suda zaključio da je za odlučivanje u sporu o naknadi za korištenje veza u luci nadležan okružni privedeni sud, jer se radi o sporu na koji se primjenjuju propisi pomorskog (plovidbenog) prava i to propisi doneseni na temelju Zakona o pomorskom i vodnom dobru, lukama i pristaništima. ${ }^{134}$

Pitanje stvarne nadležnosti bilo je sporno i u sporu za naknadu štete nastale iz štetnog događaja u kojem je motorni trajekt na redovitoj liniji pri uplovljavanju u luku prevrnuo brodicu, a oštećeni koji se u njoj nalazio pao iz brodice i dospio u radni prostor brodskih motora trajekta te tom prilikom smrtno stradao. Oštećeni nije stradao kao putnik na trajektu, pa se ne radi o sporu o prijevozu putnika morem. ${ }^{135}$ Za postupanje u ovom sporu stvarno je nadležan trgovački sud jer se spor odnosi na brodove i na plovidbu morem, a na spor se primjenjuje plovidbeno pravo (plovidbeni sporovi). ${ }^{136}$ Riječ je o izvanugovornoj odgovornosti vlasnika broda za smrt, osobe u moru koju je prouzročio brod. Bitno je da se odredbe PZ-a o izvanugovornoj odgovornosti vlasnika broda i brodara (čl. 808.-823. PZ-a) primjenjuju na sve plovne objekte, bez obzira na veličinu i namjenu kojoj služe. ${ }^{137}$

U sporu nastalom iz ugovora o popravku broda koji je prema navodima

130 VSRH, Rev-2009/1996 od 13. 12. 2000.

131 Službeni list SFRJ, br. 11/68.

132 VSRH je istaknuo da je za odlučivanje o tužbenom zahtjevu koji se odnosi na plaćanje naknade za korištenje luke za privez brodova tuženika nadležan trgovački sud, jer se radi o sporu koji se odnosi na brodove i na koji treba primijeniti plovidbeno pravo (VSRH, Gr-219/1995).

133 VSH, Gž-524/78 od 9.1.1979.

134 Zakon o pomorskom i vodnom dobru, lukama i pristaništima, Narodne novine, br. 19/1974, $39 / 75$ i $17 / 77$.

135 Na ovaj spor primjenjivala se odredba čl. 19. st. 1.t. 1 b) Zakona o sudovima, kao kompetencijskog propisa koji je važio u trenutku štetnog događaja, a sporovi o prijevozu putnika tada su bili u nadležnosti općinskih sudova. Tek izmjenama i dopunama ZPP-a iz 2013. dolazi do inkluzije sporova o prijevozu putnika u stvarnu nadležnost trgovačkih sudova.

136 TS u Zagrebu, P-1728/2003 od 24. studenog 2003.

137 Čl. 809. PZ-a. 
tužbe izvršio tužitelj po narudžbi tuženika, općinski sud oglasio se nenadležnim s obrazloženjem da se radi o sporu koji proizlazi iz trgovačkog ugovora u kojem su obje stranke trgovci. Trgovački sud je istaknuo da se ne radi o sporu iz trgovačkog ugovora jer je tuženik fizička osoba, a ne trgovac. VSRH ${ }^{138}$ je odlučujući o sukobu nadležnosti zaključio da sporna tražbina potječe iz ugovora o popravku broda, a kao mjerodavno materijalno pravo na spor treba primijeniti odredbe članka 424. stavka 1. do članka 433. ZPUP-a. Sud je posebno istaknuo da nije relevantno svojstvo stranaka, već to da se na predmetni ugovor primjenjuje plovidbeno pravo, pa je iz tog razloga stvarno nadležan trgovački sud. U ovom predmetu ne treba primijeniti odredbu o stvarnoj nadležnosti iz članka 34.b stavka 1. t. 1. ZPP-a, koji propisuje da su trgovački sudovi nadležni u sporovima između pravnih osoba, pravnih osoba i obrtnika, uključujući i trgovce pojedince, u sporovima između obrtnika uključujući i sporove između trgovaca pojedinaca, ako se radi o sporu u vezi s njihovom djelatnošću, već upravo članka 34.b stavak 1. t. 6. ZPP-a koji propisuje da su trgovački sudovi nadležni za spor na koji se primjenjuje plovidbeno pravo.

$\mathrm{U}$ sporu radi naplate novčane tražbine s osnove prodaje broda VSRH, ${ }^{139}$ odlučujući o sukobu nadležnosti između općinskog i trgovačkog suda odlučio je da je nadležan trgovački sud jer se radi o obveznom odnosu koji se odnosi na brodove. Međutim uz to, sud se pozvao i na odredbu članka 1. stavka 1. PZ-a. Treba napomenuti da članak 1. stavak 1. PZ (na koji se sud pozvao) određuje sadržaj zakona (PZ-a), govori se o tome da se odredbama PZ-a uređuju (između ostalog i) «ugovorni i drugi obvezni odnosi koji se odnose na brodove». Ugovor o kupoprodaji broda ne spada u sintagmu «drugi obvezni odnosi koji se odnose na brodove». Ugovor o kupoprodaji je normiran ZOO-om. Sintagma «drugi obvezni odnosi koji se odnose na brodove» iz članka 1. stavka 1. PZ-a odnosi se, primjerice, na izvanugovornu odgovornost za štetu, obvezni odnos u vezi sa sudarom broda, vađenjem podrtina i potonulih stvari i sl. Znači, u slučaju u kojem se radi o sporu iz kupoprodaje broda nadležan je trgovački sud jer se radi o sporu koji se odnosi na brod, a ne jer se radi u smislu članka 1. stavka 1. PZ-a o drugom obveznom odnosu koji se odnosi na brodove.

U postupku u kojem članovi posade ribarice u vlasništvu tuženika zahtijevaju kao tužitelji u sporu da im tuženik naknadi nematerijalnu i materijalnu štetu koju su pretrpjeli zbog sudara ribarice $\mathrm{s}$ tankerom, $\mathrm{VSRH}^{140}$ je zaključio da je za postupanje nadležan trgovački sud jer je riječ o sporu za naknadu štete koja je nastala sudarom brodova. Radi se o plovidbenom sporu jer se na njega primjenjuje plovidbeno pravo, znači ispunjena je treća komponenta kauzalnoga kriterija.

Treća komponenta kauzalnoga kriterija ispunjena je, ako je riječ o sporu u vezi s ugovorom o gradnji broda ili brodice, jer se na njega primjenjuju odredbe dijela sedmog, glave I. PZ-a o ugovoru o gradnji broda. Također, treća komponenta kauzalnoga kriterija bit će ispunjena ako se spor odnosi na nagradu za vađenje potonule brodice, jer se tada primjenjuju odredbe PZ-a o vađenju podrtina. Isto bi vrijedilo i za spor nastao iz ugovora o spašavanju zrakoplova u kojem sud odlučuje o nagradi

138 VSRH, Gr 224/96 od 23.10.1996. 
za spašavanje zrakoplova, jer se na njegovo spašavanje na moru primjenjuju odredbe PZ-a o spašavanju, znači, primjenjuje se plovidbeno pravo. U sporu o odgovornosti za štetu pričinjenu udarom ratnog broda u plutajući objekt primjenjuju se odredbe PZ-a koje uređuju izvanugovornu odgovornost brodara za oštećenje obale. Treća komponenta kauzalnoga kriterija ispunjena je i kada je riječ o sporovima na koje se primjenjuju odredbe PZ-a o izvanugovornoj odgovornosti brodara.

U praksi postoje pravna pitanja nastala u vezi s sporovima koji se odnose na brodove i druge plovne objekte, a koji se dotiču pitanja općeg prava i koji nisu dio lex maritima. Kao što je istaknuto, ako je spor nastao iz pravnog odnosa kupoprodaje broda, tada nije u pitanju predmet spora na koji se primjenjuje plovidbeno pravo, ali je izvan svake sumnje takav spor plovidbeni spor jer se odnosi na brod. Ono što je važno i što se u ovom radu nastoji dokazati je da se komponente kauzalnoga kriterija iz članka 34.b stavka 1.t. 6. ZPP-a međusobno nadopunjuju, pa ako je spor supstancijalno vezan uz brod i/ili plovidbu na moru treba postojati jurisdikcija trgovačkog suda, iako se na predmet spora ne primjenjuje plovidbeno pravo. Isto tako treba vrijediti i obrnuto ako se spor ne odnosi na brod i na plovidbu na moru, ali se na spor primjenjuje plovidbeno pravo treba biti nadležan trgovački sud.

Moguća je situacija da se na spor primjenjuje plovidbeno pravo, ali ta činjenica sama za sebe nije odlučna za određivanje stvarne nadležnosti u konkretnom predmetu. Riječ je o slučajevima na koje se pri izboru stvarno nadležnog suda ne primjenjuje članak 34.b stavak 1. t. 6. ZPP-a. Radi se o svim sporovima između članova posade i brodara te svim sporovima u vezi s ovrhom na brodu. PZ kao poseban propis određuje da su za te sporove nadležni trgovački sudovi. ${ }^{141}$ Određeni broj sukoba stvarne nadležnosti može se izbjeći ako sudovi vode računa o toj činjenici. To pokazuje i sljedeći slučaj iz sudske prakse. Predlagateljica osiguranja je OS u Zadru podnijela prijedlog za osiguranje novčane tražbine prisilnim zasnivanjem založnog prava na brodu (motornom jedrenjaku) namijenjenom za prijevoz putnika. Odlučujući o sukobu nadležnosti između općinskog i trgovačkog suda, VSRH ${ }^{142}$ je odlučio da je za postupanje u ovom predmetu stvarno nadležan trgovački sud jer je propisano da je za rješavanje sporova koji se odnose na brodove i plovidbu na moru i sporovima na koje se primjenjuje plovidbeno pravo nadležan trgovački sud. Točno je da se u ovom sporu primjenjuje plovidbeno pravo (odredbe PZ-a o ovrsi i osiguranju a brodu i teretu) te da se spor odnosi na brod. Međutim o stvarnoj nadležnosti suda treba odlučiti na temelju odredbe članka 841. stavka 6. PZ-a, a ne na temelju odredbe članaka 34.b stavka 1. t. 6. ZPP-a, jer je odredba članka 841. stavka 6. PZ-a lex specialis za pitanje stvarne nadležnosti u postupcima ovrhe i osiguranja na brodu.

141 Čl. 841. st. 6. PZ-a propisano je da ovrhu i osiguranje na brodu i teretu na brodu određuju i provode trgovački sudovi nadležni za pomorske sporove, a čl. 164. PZ-a propisano je da su za suđenje u svim sporovima između člana posade broda i brodara, ili poslovođe, ili kompanije, te zapovjednika i brodara, ili poslovođe, ili kompanije nadležni trgovački sudovi nadležni za pomorske sporove.

142 VSRH, Gr1-286/11 od 5. 10. 2011. 


\section{ZAKLJUČAK}

Česti slučajevi sukoba nadležnosti zorno ilustriraju da u sudskoj praksi postoje poteškoće u tumačenju i primjeni članka 34.b. stavka 1. t. 6. ZPP-a, zbog toga je očito da se ne radi o odredbi koja je nedvojbeno jasna, pa njezino tumačenje nije potrebno (in claris non fit interpretatio). U ovom radu prikazane su karakteristične sudske odluke uz njihov komentar i kritiku. Izrađeno je detaljno tumačenje ovoga kompetencijskog propisa koje bi trebalo popuniti prazninu u domaćoj doktrini, pored toga, ponuđene smjernice za njegovu primjenu koje bi trebale osigurati njegovu jedinstvenu primjenu u praksi.

Utvrđeno je da se već sada u okviru postojeće koncepcije i normativnog ustroja stvarne nadležnosti određen broj sukoba stvarne nadležnosti može izbjeći ako sudovi pravilno tumače doseg svake od tri komponente kauzalnoga kriterija (spor koji se odnosi na brod, spor koji se odnosi na plovidbu na moru i spor na koji se primjenjuje plovidbeno pravo).

Međutim, pored toga rezultati ovog istraživanja pokazuju da postojeći propis (u okvirima pravilnog dosega njegovog tumačenja i primjene) ne odgovara u potpunosti suvremenoj pomorskoj poslovnoj praksi.

Zakonodavac nije uključio brodice u doseg prve komponente kauzalnoga kriterija, pa oni sporovi koji se odnose na brodice, a na koje se ne primjenjuje plovidbeno pravo i koji se ne odnose na plovidbu na moru izmiču iz nadležnosti trgovačkih sudova. Sadašnji propis o stvarnoj nadležnosti sadržan u odredbi članka 34.b stavka 1. t. 6. ZPP-a u neizmijenjenom sadržaju (osim nadležnosti za sporove o prijevozu putnika) postoji od davne 1954. godine i nalazio se u sastavu više kompetencijskih propisa: Zakona o privrednim sudovima, Zakona o sudovima i ZPP-a. Intencija zakonodavca pri njegovom kreiranju bila je izostaviti brodice iz nadležnosti trgovačkih sudova jer se one kao mali plovni objekti rijetko gospodarski koriste i nemaju veću materijalnu vrijednost kao niti sporovi nastali u vezi s tim plovnim objekatima. Danas je situacija bitno izmijenjena. Mnoge brodice su tehnički složena plovila, koja imaju veliku materijalnu vrijednost, primjerice u nautičkom turizmu imaju istu namjenu kao i jahte, u odnosu na njih se sklapaju ugovori istog ili sličnog sadržaja kao za jahte, a sporovi nastali u vezi s brodicama mogu biti pravno složeni sporovi i sporovi visokih vrijednosti predmeta spora. Pored toga, u praksi je bitno izmijenjena struktura sporova unutar korpusa pomorskopravnih sporova koji dolaze pred sudove. Znatno je povećan broj sporova u koje su involvirane jahte i brodice, a smanjen je broj sporova koji se odnose na brodove i prijevoz stvari morem. Zbog toga je u suvremenim uvjetima odvijanja nautičkog turizma i pomorskog prometa poželjno da i o sporovima u vezi s brodicom odlučuju trgovački sudovi.

Znači, intervencijom samo na razini de lege lata izradom smjernica za tumačenje članka 34.b. stavka 1. t. 6. ZPP-a ne može se u potpunosti prevladati problem pravne nesigurnosti pri izboru stvarno nadležnog suda i problem zastarjelosti i neprilagođenosti postojećega koncepta stvarne nadležnosti. U znanstvenim ${ }^{143} \mathrm{i}$

143 Vidjeti SKORUPAN WOLFF i PADOVAN, op. cit., bilješka 7, str. 413-417 i PADOVAN i SKORUPAN WOLFF, op. cit., bilješka 8, str. 261-266. 
stručnim krugovima ${ }^{144}$ smatra se da je sazrelo vrijeme za uključivanje svih sporova koji imaju pomorskopravni karakter, pa tako i sporova koji se odnose na brodice u stvarnu nadležnost trgovačkih sudova. Očekivani cilj ostvarit će se noveliranjem niza instituta i odredbi PZ-a, kao i uvođenjem novih imenovanih ugovora u hrvatsko pomorsko pravo (ugovora o najmu jahte ili brodice i ugovora o vezu). Uvođenjem novih ugovora u PZ doći će do proširivanja kruga pravnih poslova i pravnih odnosa na koje se primjenjuje plovidbeno pravo. Reforma pomorskog zakonodavstva kroz noveliranje PZ-a izravno će utjecati na izmjene postojećega koncepta stvarne nadležnosti sudova prema članku 34.b. stavku 1. t. 6. ZPP-a, jer će posredno doći do inkluzije sporova koji se odnose na brodice u stvarnu nadležnost trgovačkih sudova. ${ }^{145}$

\section{LITERATURA:}

\section{Knjige:}

1. Jakaša, B., Udžbenik plovidbenog prava, Narodne novine, Zagreb, 1979.

2. Milošević Pujo, B., Petrinović, R., Pomorsko pravo za jahte i brodice, Pomorski fakultet u Splitu, Split, 2008.

3. Visković, N., Teorija države i prava, Zagreb, 2006.

4. Zuglia, S., Triva, S., Komentar Zakona o parničnom postupku, Vol. II, Zagreb, 1957.

Članci:

1. Barbić, J., Trgovačko sudstvo u Hrvatskoj, 50th Anniversary of the Commercial Court sin the Republic of Croatia 1954-2004, Visoki trgovački sud Republike Hrvatske, Zagreb, 2004., str. 16.-21.

2. Brežanski, J., Rješavanje sukoba nadležnosti u praksi Vrhovnog suda Hrvatske, Naša zakonitost, vol. 43, br. 9-10, 1989., str. 1219-1226.

3. Dika, M., Stvarna nadležnost trgovačkih sudova u parničnom i izvršnom postupku, Pravo u gospodarstvu, vol. 33, br. 7-8, 1994., str. 542-553.

4. Eraković, A., Stvarna nadležnost trgovačkih sudova, Pravo i porezi, vol. 6, br., 6, 1997., str. 27-33.

5. Padovan, A.V., Skorupan Wolff, V., The Repercussions of the Legal Definitions of Ship, Yacht and Boat in The Croatian Maritime Code on the Court Competence Ratione Materiae in Disputes Arising from Berthing Contracts, The Ship: an Example of Legal Pluri - Qualification, Il Diritto Marittimo - Quaderni, 3, Editor Massimiliano Musi, ASLA, BONOMO EDITORE, 2016., p. 249-277.

6. Pallua, E., Jakaša B., Pomorski sporovi u jugoslavenskom pravu, Zbornik Pravnog fakulteta u Zagrebu, vol. 10, br. 3-4, 1960., str. 258-268.

7. Pallua, E., Nekoliko napomena o odredbama Zakona o parničnom postupku u pomorskim sporovima, Naša zakonitost, vol. 12, br. 4, 1958., str. 135-142.

8. Petrinović, R., Perkušić A., Mandić N., Ugovor o najmu jahte i brodice, Zbornik radova Pravnog fakulteta u Splitu, vol. 45, br. 4, 2008., str. 863-884.

9. Radionov, N., Nadležnost suda u sporu za naknadu štete zbog tjelesne povrede putnika

144 Ministarstvo mora prometa i infrastrukture osnovalo je Stručno povjerenstvo za izradu nacrta prijedloga Zakona o izmjenama i dopunama Pomorskog zakonika. Unutar povjerenstva djeluju pojedine radne skupine između ostalog i Radna skupina za jahte i nautiku koja priprema niz novih zakonskih rješenja koja će bitno utjecati na koncept stvarne nadležnosti sudova u plovidbenim sporovima.

145 Koncept stvarne nadležnosti sudova u plovidbenim sporovima (analiza de lege ferenda) autorica ovog rada obrađuje u posebnom radu. 
nastale uslijed sudara brodova, Hrvatska pravna revija, vol. 2, br. 7, 2002., str.129-132.

10. Skorupan Wolff, V., Padovan, A.V., Smjernice za pravilan odabir stvarno nadležnog suda u sporovima iz ugovora o vezu u marini te zakonski prijedlozi de lege ferenda, Proceedings Book 1st International Scientific Conference of Maritime Law, Modern Challenges of Marine Navigation, Split, 2016., str. 379-420.

11. Skorupan Wolff, V., Odgovornost za štetu nanesenu uporabom autodizalice - osigurateljni aspekti, Poredbeno pomorsko pravo - Comparative Maritime Law, god. 52 (2013), br. 167. str. 203-205.

12. Stanković, G., Neka pitanja stvarne nadležnosti sudova u pomorskim stvarima, Pomorski zbornik vol. 34, br. 1, 1996., str. 213-229.

13. Šuc, A., Neka pitanja u vezi stvarne nadležnosti u pomorskim sporovima, Naša zakonitost, vol. 9, br. 6-7, 1955., str. 261-266.

14. Tomljenović V., Tumačenje kolizijskih pravila međunarodnih konvencija - primjer tumačenja kolizijskih odredbi Haške konvencije o prometnim nezgodama, Zbornik Pravnog fakulteta u Zagrebu, vol. 62, br. 1-2, 2012., str. 101-152.

Pravni akti:

1. Pomorski zakonik, Narodne novine br. 181/2004, 43/2006, 76/2007, 146/2008, 61/2011, 56/2013, 26/2015.

2. Pravilnik o brodicama i jahtama, Narodne novine, br. 27/05, 57/06, 80/07, 3/08, 18/09, 56/10, 97/12, 137/13 i 18/16.

3. Pravilnik o čamcima, Narodne novine, br. $72 / 15$ i 81/15.

4. Pravilnik o uvjetima i načinu obavljanja pokusne plovidbe, Narodne novine, br. 10/2008.

5. Zakon o parničnom postupku, Narodne novine br. 53/1991, 91/1992, 112/1999, 88/2001, 117/2003, 88/2005, 2/2007, 84/2008, 96/2008, 123/2008, 57/2011, 148/2011 - pročišćeni tekst, $25 / 2013$.

6. Zakon o pomorskoj i unutarnjoj plovidbi, Narodne novine, br. 53/1991.

7. Zakon o sudovima, Narodne novine br. 150/2005, 16/2007, 113/2008, 153/2009, 116/2010, 122/2010 - pročišćeni tekst, 27/2011, 130/2011.

8. Zakon o plovidbi i lukama unutarnjih voda, Narodne novine, br. 109/07, 132/07, 51/13, $152 / 14$. 


\section{Vesna Skorupan Wolff *}

Summary

\section{THE CONCEPT OF COURT COMPETENCE RATIONE MATERIAE IN MARITIME DISPUTES (DE LEGE LATA ANALYSIS)}

This paper provide linguistic and teleological interpretation of the provision of Article 34b, paragraph 1, item 6 of the Civil Procedure Act, which prescribes that commercial courts have competence ratione materiae to adjudicate in maritime disputes, and applies the competentia ratione cause criterion to define which disputes are deemed to be maritime disputes. Professional literature available does not set out precise guidelines (theoretical and practical) on the proper application of this provision. This is probably one of the causes of frequent conflict of competence ratione materiae between municipal and commercial courts that has arisen from application of this provision. In addition to the paper being focused on explanation of the concept of competence ratione materiae pursuant to the said provision, its task is to describe and comment on the relevant court practice in maritime disputes, where the issue has been raised concerning the court competence ratione materiae. The aim of the paper is to provide guidelines for correct interpretation of the contents of specific components of the competentia ratione cause criterion: (a) disputes relating to ships; (b) disputes relating to navigation on the sea and (c) disputes governed by maritime law (maritime disputes) and, on the basis of that, to define precisely which disputes, in accordance with Article 34b, paragraph 1, item 6 of the Civil Procedure Act, come within the competence of commercial courts.

Keywords: court competence ratione materiae, conflicts of competence ratione materiae, disputes relating to navigation, disputes governed by maritime law, maritime disputes.

Zussamenfassung

\section{DER BEGRIFF DER SACHLICHEN ZUSTÄNDIGKEIT VON GERICHTEN BEI STREITIGKEITEN DES SEEVERKEHRS (ANALYSE DE LEGE LATA)}

Ziel der Arbeit ist es, die sprachliche und teleologische Auslegung für die

146 Vesna Skorupan Wolff, Ph. D., Scientific Advisor of the Adriatic Institute of the Croatian Academy of Sciences and Arts; vesnas@hazu.hr. 
Bestimmung des Art. 34 b Abs 1 Pkt. 6 der Zivilprozessordnung anzubieten. Diese Bestimmung schreibt vor, dass Handelsgerichte sachlich zuständig für Streitigkeiten des Seeverkehrs sind. Ferner bestimmt die Bestimmung diese Art der Streitigkeiten nach Kausalkriterium. Genaue Richtlinien (theoretische und praktische) zur korrekten Anwendung dieser Bestimmung wurden in der kroatischen Rechtsliteratur nicht gegeben. Das ist wahrscheinlich einer der Gründe für die bei der Anwendung dieser Bestimmung entstandenen Zuständigkeitskonflikte zwischen Gemeinde- und Handelsgerichten hinsichtlich sachlicher Zuständigkeit. Neben der Erklärung des Begriffs der sachlichen Zuständigkeit laut genannter Bestimmung, stellt die Arbeit auch die relevante Rechtsprechung hinsichtlich der Streitigkeiten des Seeverkehrs, bei welchen die Frage der sachlichen Zuständigkeit der Gerichte als umstritten auftauchte. Die Arbeit versucht die Richtlinien zur korrekten Auslegung des Inhalts und Umfangs mancher Komponenten des Kausalkriteriums anzubieten, und zwar der: a) Streitigkeiten der Schifffahrt, b) Streitigkeiten der Seefahrt und der c) durch das Seeverkehrsrecht geregelten Streitigkeiten (Streitigkeiten des Seeverkehrs). Aufgrund dessen versucht man in der Arbeit genauer bestimmen, für welche Streitigkeiten die Handelsgerichte laut Art. 34 b Abs. 1 Pkt. 6 der Zivilprozessordnung zuständig sind.

Schlüsselwörter: Streitigkeiten des Seeverkehrs, sachliche Zuständigkeit, Zuständigkeitskonflikt hinsichtlich sachlicher Zuständigkeit, Seeverkehrsrecht.

Riassunto

\section{IL CONCETTO DELLA COMPETENZA RATIONE MATERIAE DELLE CORTI NELLE CONTROVERSIE MARITTIME (ANALISI DE LEGE LATA)}

Lo scopo del lavoro è quello di offrire un'interpretazione linguistica e teleologica della disposizione dell'art. 34.b co. 1. p. 6. della legge sul processo civile che dispone che per i procedimenti nelle controversie marittime sono competenti ratione materiae $\mathrm{i}$ tribunali commerciali; mentre mediante l'applicazione del criterio causale si stabilisce quali controversie si considerino liti marittime. Direttive precise (di carattere teorico e pratico) circa l'esatta applicazione di questa disposizione non vengono offerte nella letteratura nazionale. Ciò probabilmente rappresenta una delle cause dei frequenti conflitti circa la competenza ratione materiae tra i tribunali ordinari ed i tribunali commerciali, che sorgono in ragione dell'applicazione di questa norma. Oltre al fatto che il lavoro è volto a chiarire il concetto della competenza ratione materiae in forza di tale disposizione, si tenta altresì di illustrare e commentare la prassi giurisprudenziale rilevante nelle controversie marittime nella quale emerge come questione dibattuta individuare quale corte sia realmente competente. Si cerca di dare delle direttive volte ad una corretta interpretazione del contenuto delle singole componenti del criterio 
causale: a) controversie che riguardano le navi; b) controversie che riguardano la navigazione marittima e c) controversie alle quali si applica il diritto della navigazione, al fine di determinare in tale modo per quali controversie ai sensi dell'art. 34.b co. 1. p. 6. della legge sul processo civile siano competenti i tribunali commerciali.

Parole chiave: controversie marittime, competenza ratione materiae, conflitto di competenza ratione materiae, diritto marittimo. 
